\title{
What Next for the Political Economy of Development in Africa? Facing Up to the Challenge of Economic Transformation
}

\author{
David Booth \\ Overseas Development Institute
}

Sub-Saharan Africa faces an alarming long-term outlook. With a massive demographic dividend in prospect, few countries have the means to turn this to their advantage by rapidly expanding employmentintensive economic sectors. Economic analysis is facing up to this challenge, with new attention to structural change, technology absorption and the capabilities of firms. However, this article argues, it has not got to the nub of the problem. Two connected issues have been under-examined: the productivity breakthrough in agriculture without which employment-intensive manufacturing will not take off; and the weak producer incentives generated by prevailing rural social-property relations. While most economists are 'Smithian' in their neglect of property relations, political science research has done less than it might to help. Responding energetically to 'bringing the state back in', it has generated a rich body of evidence on the configurations of power that make regimes effectively developmental. But these findings remain crucially incomplete. In future, the focus should be on the political economy of bringing productivityenhancing social disciplines to the countryside.

Keywords: Africa, economic transformation, social-property relations, developmental states, political settlements

\section{INTRODUCTION}

Sub-Saharan Africa faces development prospects that are, or ought to be, alarming to anyone living in or concerned about the region. Economies are not generating anything like enough jobs and are unlikely to do so on current trends any time soon. Population and labor-force projections promise a demographic dividend that no country is in a position to cash in. Famously, in some sectors, business is booming. But the virtuous circles of productivity and income growth that have led to economic transformation in Asia are largely absent (Altenburg, 2018).

Sub-Saharan Africa (hereafter, Africa) is the region of the world that, despite unprecedented gains in various dimensions of human wellbeing, has participated least in the global economic progress of recent decades. Its projected future performance remains open but is troubling. In the coming four decades, the largest wave of young people ever will enter the world's labor market, and most of them will be in Africa. Of the 2.4 billion people who are projected to be added to the world by 2050,46 percent will be born in sub-Saharan Africa (Ncube, 2015: 89). The challenge is to ensure this is a boon, not a tragedy.

The outcome will be good only if African economies turn a corner in a decisive way. Despite a healthy pace of economic growth, over 2000 to 2014 employment expanded at less than 1.8 percent per year, far below the three percent annual growth in the labor force in that period. According to the African 
Development Bank, the region now needs to create 12 million new jobs per year to prevent unemployment rising (AfDB, 2019: 46).

Crucially, no African country has yet seen the thoroughgoing transformation in the productivity of agriculture and the rural economy that is a near-universal feature of successful development in history (Henley, 2015; Timmer, 2016; Mellor, 2017). To the extent there has been structural change, much of it follows a regressive pattern, in which low-productivity agriculture releases labor into low-productivity informal trading and services. The region has prematurely de-industrialized, and this is not yet being reversed (McMillan and Headey, 2014). Finally, Africa represents a leading example of the 'innovation paradox' - that uptake and application of modern technology is least in economies where the potential returns, in terms of efficiency, diversification and wellbeing, are greatest (Cirera and Maloney, 2017).

This article is in part a social scientist's response to these core features of the African situation and outlook. It was stimulated initially by the above-cited note by Tilman Altenburg of the German Development Institute. In Altenburg's view, there is remarkably little debate about why the economic patterns in Africa are what they are and what, if anything, can be done about them. In his view, the challenges will become more daunting still if economic, technological and environmental variables at the global level evolve as expected. Prompted by this thought, I have scanned the recent literature and revisited some older topics, in search of what social scientists seem to know already and what they need to find out if they are to help improve development outcomes over the coming decades.

The article is also, and no less, a political researcher's reflection on the particular occasion of the winding-up of the Effective States and Inclusive Development (ESID) research programme. Important in its own right, this occasion marks the culmination of 20 years of cumulative policy research on the politics and governance of development, ${ }^{1}$ a body of work that has radically improved the sophistication with which both academics and practitioners approach a range of important issues. Not all of this research has been focused on Africa, but much of it has, and all of it has implications for the more political side of the discussion of Africa's development prospects.

As well as cumulative findings and some enduring but, I believe, relatively minor disagreements, this work has generated a community of intellectual practice about which it makes sense to ask: where do we go from here? This 'we' forms one of the target audiences of the article. Governance and politics - or, as most of us would now prefer to say, political economy - research has made huge strides over the past decades, not least during the ESID years. This is a good moment for asking whether it, and we, have yet addressed all of the important questions. If opportunities should arise for research on a similar scale in the future, what are the neglected avenues of enquiry that should be opened up and addressed?

Answers to this question, in my view, need to give a central place the political economy of Africa's future. They also need to start from Altenburg's challenge regarding the adequacy of the general intellectual response to African prospects, including from policy economics, working backwards from there to political economy and politics. This is how the paper proceeds. What follows is a preview of its main argument.

Altenburg (2018) rightly drew attention to the lack of debate on some key issues. However, it is clear that the neglect is more complete in some quarters than others. Complacency about the jobless character of current economic growth does seem to be widespread among the continent's policy elites. National development plans typically set boldly aspirational per capita GNI targets to be met in future decades, but are silent on crucial aspects of how these objectives are to be reached. Robustly upbeat messages about African business success continue to sell glossy magazines and popular business books, but the downsides are too often passed over in silence.

In contrast, evidence-based literature does provide at least some of the right warning signals. Conceptual approaches have been evolving fast, with new attention to transformation processes and organizational capabilities, among other things. The leading edge of academic social science is closer to addressing the core of the African development challenge than it was a few years ago. Much of this is now reflected in the flagship publications of the African Development Bank (AfDB, 2016; 2019) and in discussions at the best international forums. 
In other words, there is relevant discussion. Two things are much less clear, however. One is whether the gap between the best thinking and the general state of the policy discourse is closing as fast as it must. The other is whether the most advanced discussion has yet reached the nub of the problem.

In important respects, I propose to argue, the main policy literature is still framing the political economy of economic transformation in Africa in ways that evade uncomfortable yet vital matters. In the first place, the crucial interdependencies between manufacturing prospects and agricultural transformation continue to be underplayed. And, secondly, the theory being applied to the challenges of rural development remains strangely silent on matters that history tells us are fundamental. The literature suffers from a blind spot and a shortage of research on an issue that easily falls between the two stools of an economics firmly focused on market opportunities and capabilities, and political research narrowly concerned with the effectiveness of states. This blind spot concerns the incentives generated - most importantly in agriculture - by the prevailing social-property relations.

Addressing this gap involves, as first step, resurrecting some arguments about the nature and origins of capitalism that were central to debates among Marxist academics in the last century and retain their value, in spite of the shortcomings of much the associated literature and most of the politics. Those arguments center on an issue on which Karl Marx was proven right in his reworking of the ideas of Adam Smith.

Even the best of the current discussion remains 'Smithian' (as per Brenner, 1977; 2007), in that it focuses helpfully on market opportunities and missing capabilities but neglects the changes in producer incentives - rooted in social-property relations - that are no less required if the necessary investments in productivity are to occur. While the Brenner thesis has been most directly associated with the origins of capitalism in Europe, and England in particular, its fundamental insights regarding incentive structures in agriculture are fully confirmed by historical experience across the world. These insights seemed relevant in Africa 40 years ago, the last time Africa's future was subjected to a serious amount of thinking outside the box of mainstream economics (e.g., Hyden, 1983); but they have since been largely forgotten.

Giving proper attention to the problem of social-property relations is a sine qua non for a realistic response to the African transformation challenge. While there is plenty of literature relevant to this topic, including in-depth treatments of particular historical periods and groups of countries, little of it has addressed the specific, present-day problem that we are concerned with here. Both research and policy thinking need to be addressing much more explicitly how, in the absence of any of the historic forms of agrarian transition to capitalism, a functionally equivalent reshaping of incentives might be engineered, for example, through more vigorous state action to link smallholders with modern corporate businesses, including in food value-chains.

The first step of refocusing on rural producers' incentives sees unlikely to be taken if it is not accompanied by a shift in the focus of research on the state and its role in development. There is no doubt that the key variable affecting Africa's ability to replicate the development successes of Asia - including the adoption of effective agrarian incentive structures - is the character of the state and the prevailing pattern of politics. There are no private sector solutions that can work without deliberate steering by the state. At the same time, however, the present character of the state is bound up with the present nature of the society, including the rural social relationships, in which it is embedded, as was clear to Hyden and later to Chabal and Daloz (1999), among others.

Recent research on states and development has been impressive in both volume and quality. Thanks to ESID in particular, we now know a great deal about a large range of issues in the political economy of improving development outcomes. However, very little of this work has addressed the crucial topic of social-property relations and their transformation, either as a dependent variable or as a shaper of politics and the form of the state.

There is a history to this. In the 1980s, during the turn to 'bringing the state back in' (Evans et al., 1985), we in the political research community went further than was necessary in downgrading the analytical links between state-building processes and the emergence of capitalist economies. We overcorrected for the economic reductionisms of the previous period in Marxist and other development theory and narrowed too far the range of questions it is sensible to ask. Influenced by a partial understanding of the roots of developmental success in East Asia, we came to focus too exclusively on the ability of political 
regimes to commit to long-term goals and implement corresponding policies, and too little on other relevant factors.

We need, in the future, to complement the best work in this vein - such as that which has generated influential typologies of 'political settlement' - with a fresh look at two long-established but still relevant themes. We should seek, on the one hand, a sharper awareness of how the limitations of African states stem, at least in part, from the non-capitalist societies in which they are embedded; and, on the other, an appreciation that the qualities that make regimes more or less 'developmental' include a willingness and ability to facilitate effective capitalist penetration of the countryside. These themes have been touched on in recent literature, but there are huge gaps to be filled.

The remainder of this article falls into two main parts, devoted to the economic and the political aspects in turn. The first part sets out the core challenge, based on an extensive review of recent literature in applied economics. The corresponding challenge from the perspective of politics research and political economy is picked up in the second part. I then conclude by summarizing the implications for research and practice.

\section{THE ECONOMY AFRICA NEEDS: WHAT WE KNOW AND WHAT WE DON'T}

What sorts of research problem are posed by the African development outlook? What do we know already and what knowledge is lacking? This section argues that economic understanding of some of the most important issues has improved fast, from a low base, over the last decade, leaving a big challenge of policy uptake and political feasibility. However, in two important respects, it has not got to the nub of the problem. The analytical agenda needs to be expanded, specifically to include the producer incentives generated, or not generated, by prevailing social-property relations, especially in agriculture. Let us start with what we know.

\section{From Growth to Transformation}

Most obviously, we know we were content for far too long to concentrate on the problem of sustaining acceptable rates of economic growth. Hypnotized by the remarkable turnaround in the region's growth performance from the mid-1990s onwards, Africa-focused policy economics failed to ask basic questions. The fact that much of the growth was occurring within an untransformed, even 'colonial', production structure escaped mainstream attention for years. The critical concept, 'economic transformation', began to hit the magazine cover stories as recently as 2011 (Amoako, 2011). Only a year before, the sustained growth rates (and evidence of democratization) registered by a set of leading countries were still dominating the headlines (McKinsey Global Institute, 2010; Radelet, 2010).

Among economists, part of the problem was theoretical. The most influential channels of policy advice relied quite heavily on theory borrowed from efforts to understand the business cycle in developed Northern economies, theory in which appreciation of the history of development played a small part. In the thrall of the latest advances in economic growth theory, economists forgot what they had once known about the role of structural change in development. The evidence of economic history - on the role of agricultural productivity in the initial stages of development (Timmer, 2007; 2016), on the 'special economic magic' of manufacturing (Reinert, 2007; Cimoli et al., 2009; Whitfield, 2012; Rodrik, 2013) and on pathways to catch-up in a world of global value-chains (Monga, 2013; Studwell, 2013) - received only marginal attention (Monga and Lin, 2019a).

In a critique of the so-called post-Washington Consensus around the turn of the millennium, John Sender wrote:

'No attempt has been made to come to grips with the conceptual limitations of aggregate production functions as tools for understanding the structural changes associated with growth ... or with analyses that focus on the crucial role of the manufacturing sector as a source of dynamic increasing returns' (1999, p.108).

It took a decade for this to change significantly. 
In the interim, the hegemony of economic growth theory helped to sustain the illusion that Africa's developing economies are essentially immature versions of OECD-type economies. The corresponding policy advice was bland and unhelpful. Typically, it consisted of an unprioritized menu of recommendations designed to support the accumulation of physical, human and, later, learning capital, the sum total of which was so daunting as to be effectively non-actionable (Monga, 2019). The polite fiction that low-income and high-income economies are fundamentally similar may have served to lubricate the 'policy dialogue' between international experts and African leaders but it also rendered it less useful.

Today, policy economics for Africa is increasingly focused on the challenge of economic transformation, understood as a process in which productive resources move from low productivity to higher productivity sectors and activities (ACET, 2014; 2017; McMillan et al., 2017b). This has brought overdue attention to, among other things, the role of firms and national innovation systems in the learning and other capabilities that lead to productivity growth (e.g. Stiglitz and Lin, 2013; Altenburg and Lütkenhorst, 2015; Gelb et al., 2015; Altenburg et al., 2016; Newman et al., 2016).

\section{Firms, Organizations and Clusters}

The theoretical import of this shift must be noted. It establishes the relevance to Africa of Schumpeterian and other perspectives on entrepreneurship and organizational arrangements, based on historically informed, or 'evolutionary' (Nelson et al., 2018), economics. The 'myth of the market economy', the inadequacies of the neoclassical theory of the firm and the importance of taking firms seriously as organizations, had been the subject of important but relatively uninfluential scholarly work for many years (Lazonick, 1991; 1992). It is now on the verge of the mainstream.

Addressing the 'innovation paradox', a stream of work at the World Bank is focusing on the capabilities of organizations, including: the managerial practices of firms and the robustness of national innovation systems (Cirera and Maloney, 2017); the impact of operating environments and human capital on productivity (Cusolito and Maloney, 2018); the distinguishing features of High-Growth Firms (Grover Goswami et al., 2019) and - last but not least - technology and productivity growth in agriculture (Fuglie et al., 2020). This is significant and to be welcomed.

Especially when harnessed together with the 'new structuralist' trade theory of Justin Lin (2012), the focus on organizations and capabilities has resulted in a new high in terms of the quality of available policy advice. The best of the work in this tradition has shown us the kind of ambitious pragmatism that could work to jump-start economic transformation in Africa in the 21 st century and respond to the challenge of the demographic dividend (Lin and Monga, 2017; Monga and Lin, 2019b).

What should be prioritized, according to Lin and Monga, is productive activity in which a country has a 'latent' (not current) comparative advantage. The mechanism of specialization is the industrial cluster the proper form of Special Economic Zone (SEZ). There is a telling case to be made for not trying to solve all of the problems of poor developing countries simultaneously. Long laundry lists of preconditions for successful economic transformation are an unhelpful basis for policy. Policy should be about consistent prioritization, so that available resources are focused on getting the most promising activities started and showing appreciable benefits, rather than spread thinly across the whole economy. Clearer, more practical and more politically inviting advice has rarely been offered.

Questions remain as to how far these ideas are being translated consistently into watchwords for action at the front line of policy making and implementation. Buzz-words such as 'economic transformation' tend to get accepted and inserted into speeches far quicker than the underlying thinking, with advanced ideas still sitting alongside examples of the old, bland policy messaging in official publications. However, this is not the only issue of concern.

\section{Have We Got to the Nub of the Problem?}

The other issue - to which the remainder of the article is largely devoted - is whether the advanced thinking is sufficiently advanced in all important respects. The argument is going to be that it is not.

Help in constructing such an argument is to hand, in the form of the encouragingly rich, empirically grounded literature that has grown up in recent years, at the same time as the above-mentioned shifts in 
theoretical and policy focus. Complementing the theory and the policy advice on industrial policy is a growing body of case-study research on firms, sectors and innovation systems. This includes the comparative research on economic sectors in Africa under the Elites, Production and Poverty (EPP) programme (Whitfield et al., 2015); the best analysis of firm and household survey data in or around the World Bank, the International Food Policy Research Institute (IFPRI), the Center for Global Development and the Centre for the Study of African Economies in Oxford; the company mapping operations funded by the International Growth Centre; and the research programme for ESID begun by Pritchett et al. (2017) and extended by Behuria (2019).

Taken as a whole, this rich, although rather dispersed, body of work provides a useful starting point for further interrogation of the African transformation challenge, and for addressing the question of the adequacy of our current conceptual frameworks. In the following pages, I argue that the surveys, firm case studies and sector-by-sector institutional analyses that make up the bulk of this work suggest more than their authors have been able or willing to theorize explicitly. In most cases, analysts have remained rather timid about confronting some of the issues they have documented empirically.

In different ways, the contributions I cite raise doubts about the sufficiency of a framework that deals effectively with opportunities and capabilities, but fails to ask fundamental questions about two issues: 1) agriculture-industry linkages; and 2) the incentives generated by prevailing social-property relations.

\section{Current Patterns in Agriculture and Manufacturing}

The empirical literature documents the following features typically underlying the halting results of agricultural and manufacturing development among some of Africa's leading economies:

- In food agriculture, the continued shortage of the kind of organized linkage to the wider economy that would both enable and compel substantial investments in productivity. In countries like Kenya and Tanzania, policies for developing food agriculture have focused on improving production, to the neglect of creating efficient and sustainable value chains leading from the farmer to the urban consumer and beyond (Karugia et al., 2010; Gollin and Goyal, 2017; Obasanjo et al., 2018). That is the case despite the well documented potential of corporate firms, including supermarket chains (Weatherspoon and Reardon, 2003; Reardon et al., 2009) and commercial input suppliers, to organize agricultural inputs and outputs effectively, thereby 'internaliz[ing] many of the externalities that lead to inefficiencies in traditional agriculture' (Barrett et al., 2017, p. 14).

- In other agriculture, the persistent failure of efforts to capitalize on the demonstrated ability of well-regulated contract farming/out-grower schemes to raise farm productivity closer to international levels (Felgenhauer and Wolter, 2008; Sangho et al., 2011; World Bank Group/Government of Rwanda, 2019, p. 41). Even when the policy context has provided a potential entry-point for corporate involvement in the organization of supply, the necessary market disciplines to prevent problems such as 'side-selling' have often not been provided, which has undermined the incentives of the corporate actors (Fafchamps, 2004, pp. 479-480; Poulton et al., 2010; Whitfield et al., 2015, Ch 9; Whitfield, 2018, Ch 5-6; Booth, 2019; Mills, 2019).

- In agribusiness, the lack of reliable local supply on a sufficient scale, combined with vested interests in food importing (Matsumoto-Izadifar, 2008; Wolter, 2008b; 2008a), leading regional investors to concentrate on processing imported grains to serve regional markets, an activity that generates very few jobs, directly or indirectly.

- In manufacturing, the long-recognized problem of the 'missing middle', where the majority of firms are small and remain so, while most large firms are in the hands of either the state or members of ethnic minority groups (Ndulu et al., 2007, pp. 75-77; Ramachandran et al., 2009; Dinh and Clarke, 2012; Gelb et al., 2015; ECA, 2017). As Ramachandran et al. put it, 'further broad-based growth of manufacturing can occur only with the participation of domestic businesses, including those of the indigenous majority' (ibid., p. 54). ${ }^{2}$ Some of the reasons this 
is not straightforward are suggested by Fafchamps' research $(2004 ; 2011)$ on the character of the prevailing market institutions, notably the continued reliance of successful firms on informal networking, rather than either formal institutions or formal networks, as means of sustaining the trust necessary for long-distance transactions. This feature, with its tendency to enhance the position of existing business communities and slow the emergence of new players, inhibits dynamism, both through its direct effects on potential new entrants and indirectly by adding an ethnic dimension to any anti-capitalist sentiments prevailing in the political system.

Analysis of firm data across Africa and other developing regions shows that only 40 percent of the size gap between African firms and those in other regions is explicable in terms of firm and market characteristics and the business environment, with 60 percent remaining as an unexplained 'Africa effect' (Iacovone et al., 2014). Possible explanations include long-neglected issues concerning trust, at 'micro' level, as firms transition away from family-only employees, and the steep premium on the cost of labor incurred by larger firms. The former would point to the conclusion that too many of the 'firms' are not actually capitalist enterprises. The latter may be part of the wider problem that, compared to countries like Bangladesh, Vietnam and India, formal wage rates reflect a higher cost of living (Gelb et al., 2013; Ramachandran, 2015), in part a result of the low productivity of food agriculture.

\section{The Pivotal Challenge of Innovation in Agriculture}

The last point - about the failure to establish in Africa the transformative interlinkages between agricultural improvement and employment growth in manufacturing - is fundamental. The well-established literature on agricultural transformation (Timmer, 1988; Mellor, 1995; Breisinger and Diao, 2008; Tsakok, 2011; Timmer, 2015; Mellor, 2017; IFPRI, 2019) is clear on this. Successful economic transformation begins with and depends on substantially raised productivity in agriculture. Higher farm incomes generate demand for rural and small-town services and manufacturing, permitting poverty to be reduced and large numbers of productive jobs to be created even as the labor needed in agriculture declines. In turn, improvements in farming methods and rural-to-urban logistics reduce the price of food in cities, which contributes, along with complementary improvements in transport and housing, to the competitiveness of the wage rates available to investors in manufacturing.

It is increasingly hard to argue that these long-established generalizations about the importance of intersectoral linkages do not apply to Africa. Debate continues as to the relative viability of small- and largefarm approaches to agricultural commercialization and modern technology absorption (e.g., Hazell et al., 2010; Collier and Dercon, 2014; Cramer et al., 2020). Nonetheless, the bulk of the evidence agrees on two things.

First, agriculture is growing at a pace that demonstrates potential to contribute in the indicated ways to overall transformation (FAO and World Bank, 2009; Wiggins, 2018). A principal driver of this progress is growing urban demand and changing urban and rural food preferences, factors that are also generating a 'hidden middle' of small- and medium-sized processors, transporters and logistics operations (Reardon, 2015; Tschirley et al., 2015). For leading experts, this 'quiet revolution' is inducing in a number of countries an 'unfolding economic transformation' (Jayne et al., 2018; AGRA, 2019).

Second, this process is dynamic but not yet economically efficient, and is far from the international frontier in terms of both agricultural technology absorption and the efficiency of procurement, processing and logistics (Skarstein, 2005; Juma, 2011; ACET, 2017; Barrett et al., 2017; Cramer et al., 2020, Ch 9; Krishnan et al., 2020). As a consequence, its ability to generate off-farm employment in rural areas is not sufficient to stem the outflow of labor into low-productivity informal service activities in increasingly congested cities (Haggblade et al., 2007; Losch et al., 2012; Mueller and Thurlow, 2019). And, in the cities, food remains expensive.

The importance of inter-sectoral linkages is generally acknowledged in the manufacturing-focused literature referenced earlier. The evidence in support includes rigorous paired comparisons of African and Southeast Asian development experiences over the past 60 years that make clear that lagging performance in Africa is due in all cases to less favorable policies towards rural development (Henley, 2015). It cannot be said, however, that the full implications of this finding have been taken on board. It remains common 
for the Asian model that Africa seeks to emulate to be characterized as 'labor-intensive manufacturing', with scant attention to the prior matter of agricultural transformation. It is also increasingly common to hear that future development and climate-change responses will be so driven by knowledge-based innovation that it is unwise to take any firm view - even in the light of overwhelming historical evidence - as to whether agriculture should get priority. The conceptual limitation to which we now turn our attention must been seen in this context.

\section{Missing Theory: Producer Incentives and Social-Property Relations}

As we have seen, recent discussion of Africa's transformation challenge has widened the agenda of economic analysis, from market opportunities and constraints (infrastructure, skills, etc.) to the capabilities of firms and other organizational matters. However, particularly in view of the critical role of the agricultural part of economic transformation, I argue that the analytical agenda needs a substantial further expansion. Specifically, it needs to include the incentive structures generated, or not generated, by prevailing social-property relations. In the final analysis, very many of the blockages or unrealized potentials itemised above are due to actors having other options than investment in production and productivity, and to these alternatives not having been closed off by either policy choices or socio-economic trends.

I want to suggest that the theory relevant to these broader concerns is to be found in a part of the tradition of Marxist scholarship that has been unduly neglected by mainstream development economics. ${ }^{3}$ The following are its key insights.

In history, the difference between dynamic and non-dynamic economies is not fully explained by differences in either market opportunities or organizational capabilities, or even the two combined. The comparative facts are only sufficiently explained when we pay attention to the incentives faced by farms and firms as a result of their location in different types of social-property relations.

Readers with sufficiently long memories may recognize here the central propositions of historians Robert Brenner (1977; 1985a; 1985b; 1986; 2007) and Ellen Meiksins Wood (1999). The terminology of social-property relations is Brenner's and is adopted purposely in place of the more conventionally Marxist 'social relations of production'. While Brenner and Wood were largely concerned with the early origins of capitalism in England and the Netherlands, other historically oriented scholars who consider a broader canvas of comparative cases, including Prussia, the USA and India, take a similar view on the fundamental theory (Byres, 1996; 2009). The main submission of this article is that the work of this school of historical research is more relevant to today's challenges in Africa than, in recent times, we have been willing to admit. $^{4}$

The 'Brenner thesis' famously contends that in Europe between the 17th and 19th centuries, the big breakthroughs in agricultural and then industrial productivity, first in England and then in the Low Countries, were not prompted either by demographic events (the Black Death, etc.) or by the general spread of trading relationships. Neither of these types of factors account adequately for the geographical unevenness of the economic outcomes. The pattern of outcomes can only be explained by the differential impact of demographic factors and trade expansion in regions with different social-property relations.

England got its initial lead in agriculture when landowners were induced to become improving landlords', as a result of political changes that closed down their ability to maintain their privileges by previous, extra-economic, means. Tenant farmers were forced by increasing rents to either invest in productivity or move out. In other parts of Europe, where the social-property relations in the countryside had not been evolving as in England, the growth in agricultural trade in this same period led to more or less grave economic retrogression, including, in the east, a 'second serfdom'. In the following centuries, English agrarian capitalism created the social and market conditions that enabled the application of new technologies by capitalist firms in textile and other industries, producing the first industrial revolution.

Brenner dubbed the analysis that places the accent on growing opportunities through trade 'Smithian', on the grounds that Adam Smith's core argument in The Wealth of Nations is that trade enables an increasing division of labor, which in turn leads to the discovery of more efficient production processes. As was first pointed out by Marx himself, this takes for granted the existence of social groups that are no longer 
able to respond to trade opportunities in traditional, zero-sum ways, using extra-economic levers, and therefore have no option but to become more efficient

Smith was inclined to make this assumption, writing as he was in the midst of the socio-economic changes in Britain that had created these historically unprecedented circumstances. However, the comparative history of the period does not support such an optimistic vision of the transition from medieval commercial capitalism to modern industrial capitalism.

Profit-making businesses taking control of production processes and not just trade operations was an uncommon phenomenon in the 18th and early 19th centuries, effectively limited to Britain and its settler offshoots in the Americas and elsewhere. In the course of the 19th and 20th centuries, this changed, particularly as states, mainly for strategic reasons, became active promoters of transport infrastructure and factory-based industries on the English model. While these purposeful interventions widened markets and created opportunities, they were most successful where they also addressed the incentives arising from the social-property relations predominating in agriculture, as in the otherwise contrasting cases of Prussia and the USA. They were less successful where they found that challenge too daunting, as in France (Clapham, 1968; Byres, 1996; 2009). In no case did the problem of non-capitalist rural social-property relations take care of itself.

\section{Brenner and East Asia}

Over the years, many have argued rightly that Africa should be looking to Asia, especially East Asia, not Europe, for models. This article might seem to be advocating an unhealthy revival of Eurocentrism at the expense of everything we have learned about multiple development pathways. Obviously, Africa today is not early modern Europe. However, the conceptual clarity achieved in analyzing the latter may nonetheless be helpful in reconsidering the former. Furthermore, there are grounds for thinking that in Asia, no less than in Europe, the diversity of the political regimes that have presided over successful development has obscured some important commonalties regarding the conditioning of economic outcomes by socioeconomic factors.

The visions of development success taken away by Africanists from East Asian, and to a lesser extent Southeast Asian, experiences have tended to be focused on the economics of export manufacturing and the politics of responding to strategic challenges and shocks. However, some of the less widely read parts of the literature on Asia point to aspects that may be more immediately relevant to Africa's present dilemmas.

To begin with, there are strong grounds for regarding Asian agrarian transformations as the indispensable prelude to industrial success. Burmeister's work $(1990 ; 2006)$ has shown how South Korea's manufacturing take-off depended on a simultaneous 'green revolution' policy that achieved significant import substitution and stimulated domestic inter-sectoral growth linkages in critical ways. This involved a good deal of compulsion against peasant and technocratic resistance. The literature on Taiwan (Myers and Ching, 1964; Amsden, 1988; Tomich et al., 1995) traces the origins of the country's development dynamic to the much earlier introduction of science-based farming by the Japanese colonial administration, when recommended practices were adopted by producers under pressure from both landlords and the state. As in Korea, the land reforms of the 1950s reduced the landlord intermediation but not the level of compulsion (Moore, 1988).

\section{Smith Versus Marx in Africa Today}

Brenner generally sticks closely to his specialist fields as a professional historian, but in at least one passage he ranges more freely, helping to establish the relevance of the historical evidence to the themes of this article. Suggesting that the overwhelming majority of today's development economists and economic historians remain 'Smithians at heart', he writes:

'They would not perhaps contend that the mere application of individual economic rationality will, directly and automatically, bring about aggregate economic development. But they would argue, that, given the appearance of certain specific, quite-reasonable-toexpect exogenous economic stimuli, rational self-interested individual economic activity 
can indeed be expected to detonate a pattern of growth. It is their hypothesis, that in responding to these external stimuli and the opportunities they create, rational selfinterested individuals will in fact ... act like capitalists ... and, in so doing, will bring about the transformation of pre-capitalist to capitalist property relations' (Brenner, 1986, p. 35; emphasis original).

This article's proposition is that the recent advances in thinking about the African development challenge are, in the Brenner sense, Smithian. That is, there is an underlying assumption that if the specified opportunities and capabilities were to be provided, productivity-enhancing investment behavior would be elicited. In other words, such behavior would occur naturally if the context were to improve - with, for example, not just a sound business climate and more publicly provided infrastructure, but also a favorable sectoral 'deals environment' (Pritchett et al., 2017) and well-tailored support to the capabilities of households and firms.

Such assumptions may seem intuitively plausible, as well as helpfully upbeat, but they are not consistent with one of the central findings of comparative economic history. The socio-economic preconditions for capitalism to penetrate the sphere of production are specific and quite demanding. This is so because it is historically uncommon for other, more established and therefore 'easier' options not to be available. In agriculture, the easier options include the subsistence-oriented household, where minimizing livelihood risk takes precedence over raising productivity, and the holding of potentially productive land as an adjunct to the exercise of political power or a badge of social status. In most historical settings, closing these options has been difficult and painful, involving both social distress and bitter political battles. However, I suggest it is an illusion to believe it is a process that can be avoided in Africa.

One of the handful of currently influential strands of economic analysis that recognizes the relevance of this history in today's developing countries is the one inspired by Mushtaq Khan. I discuss Khan's work more fully, in connection with political settlements theory in the second part of this article, but the following is relevant here.

Citing Brenner and Wood, Khan (2005) argues that today's developing countries may not be able to avoid a changes equivalent to the historic great transformation 'from pre-capitalist or largely pre-capitalist societies, where markets created opportunities but not an over-riding set of social compulsions, to capitalist societies, where markets operated to compel maximization of profit and continuous productivity growth' (pp. 74-75, emphasis original). East Asian experience shows that successful catching up requires institutions and interventions that are different from those in classical capitalism, but not that the element of compulsion can be avoided, since 'creating a capitalist economy always requires substantial restructuring of pre-existing property rights and incentives for emerging capitalists to rapidly acquire new technologies' (p. 79). Khan agrees, therefore, that mainstream policy thinking, with its emphasis on well-functioning markets (and, we might now add, capabilities), makes the mistake of assuming that a capitalist transformation has already taken place (ibid.). ${ }^{5}$

Nearly 40 years ago, a broadly similar thesis was advanced in Goran Hyden's No Shortcuts to Progress (1983). Hyden famously drew attention to the distinctively 'uncaptured' character of African peasantries; that is, the almost complete absence of either the landlord-tenant relationships or the effective state presence in the countryside that in other parts of the world put pressure on rural households to adopt new technologies and raise yields. For him, this was not a matter to be celebrated but a problem to be more widely recognized:

'Africa needs a new paradigm, or a set of new paradigms, that better incorporates the fact that Africa is still essentially pre-capitalist, and what we witness on the continent, by and large, is the battle between the forces defending these formations and those - still much weaker - trying to conquer them. This is a very different struggle from the one that has been going on in the imagination of most observers and actors on the African scene' (pp. 193-194). 
If that is the case, it is remarkable how little of the best research on recent trends in agriculture and food value chains, such as that cited earlier, concerns itself with the incentives generated by the prevailing socialproperty relations. We know a good deal about the history of agrarian change, including the role in it of various types of African capitalist class (Sender and Smith, 1986; Lubeck, 1987; Berry, 1993; Berman and Leys, 1994; Boone, 2003), but these studies, both empirically based and informed by classical Marxist concerns, have generally not been updated. As history, the promise and the pitfalls of reforms to formalize property rights in land have also been well covered (Berry, 1993; Toulmin and Quan, 2000; Byamugisha, 2013; Boone, 2014). As a teaching and research discipline, the institutional economics of African agricultural development is well established and does address current themes and issues (Kirsten et al., 2009, and related citations above). But there has been little published work focused specifically on the possible interactions between new forms of corporate intermediation (agribusinesses, supermarkets, etc.) and the emergence of either new forms of capitalist farming or more firmly state-disciplined commercial smallholdings.

There is, of course, a literature on contract farming (CF) but as the best survey concludes, 'the connections between $\mathrm{CF}$ and the development of capitalism, especially the emergence of domestic agrarian capital in developing countries, are somewhat tenuous if not absent in most of the literature' (Oya, 2012, pp. 23-24). In this connection, we still know little about the potential implications of the so-called 'land grabs' of the last decade, except that they have probably been over-hyped (Holmén, 2015). For its part, the more Marxist-oriented contract-farming work (e.g. Little and Watts, 1994) has been too preoccupied with global-system issues and too little with domestic causes and outcomes, and the potential for their improvement. Only recently, and thanks to ESID researchers (Behuria, 2020; Tyce, 2020), has a similar bias in the bulk of the value-chain literature begun to be corrected.

Current analysis in the mainstream has some obvious blind spots. For example, IFPRI work on the feasibility of moving smallholders 'from subsistence to profit' (Fan et al., 2013) proposes a typology of smallholder farms based on the degree to which they are subject to a range of hard and soft constraints. But, the question of why, in the absence of such constraints, subsistence farmers 'with profit potential' should be expected to become profit-maximizers, given the availability of other options, is evaded. As in the food policy literature more generally, there is an unwillingness to face up to the element of compulsion - by landlords, state agencies or some combination of the two - that was present in nearly all successful rural transformations in history.

The best analysts are no doubt aware of this gap, but they may not be able to fill it with the information and methods to hand. Most survey data refer to disembodied entities, either 'households' or 'firms'. In both cases, the respondents are typically a very mixed bag, including a variety of types of economic operation. The degree to which they include either fully fledged capitalist firms or household producers subject to capitalist disciplines, though formal or informal contracts, is usually completely unclear. Despite the new theoretical interest noted earlier in bringing organizations and their capabilities to the fore, we are still largely in the dark about the kinds of producer incentives that better organized food supply chains and capability-building initiatives need to contend with if they are to be effective.

An important exception to this generally dismal record is work from the Economics Department of the School of Oriental and African Studies at the University of London. The key publication here (Cramer et al., 2020) advocates a robust 'possibilism', based on the varied economic performance of countries across space and time, and a skeptical take on aggregate statistics. It contrasts this position with the naïve optimism of influential international organizations concerning the potentials of small and medium-sized enterprises, rural cooperatives and small farms, as well as with exaggerated views on the perils of world markets. Drawing on the ideas of Kaldor, Kalecki and Hirschman, rather than on the 'new structuralism' of Monga and Lin, the authors nonetheless converge (more than they are willing to admit, I believe) with the recent thinking about industrial policy cited at the beginning of this article - on the importance of prioritization; on the need to raise investment, including by the public sector; on the virtues of employment-intensive production for large markets; and on the special gains from manufacturing (increasing returns, etc.). They add substantially to the previous literature in three ways.

Journal of Applied Business and Economics Vol. 23(3) 2021229 
First, they issue a strong reminder of the point that efficiency in the production of 'wage goods', and thus tackling the principal constraints on the production of cheap food, such as lack of irrigation, is the key to the profitability of investment in export manufacturing. Second, they argue, and show for the case of flower farms in Ethiopia, that large-scale technologically advanced production in agribusiness can capture the gains typically associated with manufacturing, and indeed do better in this regard than many assembly operations (see also Cramer et al., 2018). In short, such 'agricultural' enterprises should count as manufacturing in policy discussions. Thirdly, widely disseminated analysis of survey data by IFPRI and others understates the extent to which wage labor, especially wage labor in large, corporate enterprises, is already a feature of the rural scene in many African countries. In this way and others, the need to base development strategies on smallholders has been greatly exaggerated in the policy literature.

All in all, Cramer and his colleagues provide us with an exceptionally thorough and closely argued restatement of the case for seeing development progress as inextricably linked to the advance of capitalism, starting in the countryside. The argument does have a blind spot, however. It has little to say about the part in the agricultural productivity revolution that will, after all, need to be played by smallholders of a certain size. Even if they are entirely right about the actual and potential role of large farms, it is hard to see this as a total solution. And the burden of the international, including Marxist-oriented, literature cited earlier is that the critical variable is not scale of operations, but the extent to which operations of any size become subject to capitalist disciplines as a result of subordination to landowners, banks, the state or some combination of these. Therefore, it would have been helpful if some of their research had been dedicated to how the various corporate intermediary organizations itemized earlier might come to play such a role in Africa in future decades. ${ }^{6}$

\section{'Entrepreneurship'?}

In at least some respects, the literature on non-agricultural sectors is ahead of the rural development field. In connection with manufacturing, the topic of 'entrepreneurship' has attracted some attention. Even in this context, however, the discussion seems to proceed on the assumption that capitalist producer firms already exist on a significant scale, so that attention can focus exclusively on expanding their opportunities and/or building their capacities. A partial exception is the excellent section on entrepreneurship and industrialization in the 2017 African Economic Outlook (AfDB, 2017). This does go beyond building the capacity of an assumed category of suitably motivated producers in at least a couple of respects.

First, the Outlook authors refer to the distinction in the entrepreneurship literature between opportunitydriven and rent-seeking entrepreneurs. They then cite the survey result that 44 percent of African entrepreneurs self-declare as having started business to exploit opportunities in the market, while 33 percent admit doing so because they cannot find other jobs. The set of recommendations offered on the first issue includes ending indiscriminate subsidies and avoiding policy capture by incumbent firms. Advice on the second includes encouraging 'survival entrepreneurs' to shift to wage employment and targeting short, demand-driven training at entrepreneurs identified as opportunity-driven. Solid guidelines are also given on how business clusters and SEZs can help firms overcome growth constraints.

In the final analysis, however, the concept of the entrepreneur 'driven by opportunities in the market' is rather loose and probably suggests more than it should about the extent of genuinely capitalist decisionmaking. Market opportunities are a necessary condition for capitalist investment behavior, but not a sufficient condition. For investment in innovation to become the norm, there need to be arrangements that both enable and enforce adoption of the best available technologies and management methods. It is hard to see this happening other than by subordination of the promising smaller enterprises to established corporate firms, with an element of compulsion and technology transfer going well beyond ad hoc training schemes. As a minimum, the hard realism applied to the survival entrepreneurs (effectively, 'get a job') needs to be matched with equivalent advice to the others ('if you are serious, find a corporate partner').

The previously cited Outlook for 2019 (AfDB, 2019) is similarly solid on the links between employment generation and dynamism among manufacturing firms, making sound recommendations on more coherent and better targeted policies. However, it too avoids consideration of the socio-economic context in which limited firm dynamism is observed. It leaves room for doubt about whether, if the 
identified problems of corruption, unconducive regulation and inadequate infrastructure were to be addressed, the necessary economic innovation would be forthcoming.

Similarly, Ramachandran et al. (2009) join McMillan et al. (2017a) in calling for more deliberately selective support: 'reforms that benefit a large number of firms ... should be pursued as energetically as those focusing on trade, which may be seen as benefiting importers and larger exporting firms more than anyone else' (p. 85). However, this does not respond sufficiently to the repeated indications in the literature that firms that are both capitalist in their internal incentive structure and not benefiting from indiscriminate subsidies are extremely thin on the ground. Nor, of course, does it deal with the roots of this situation in the lack of even incipiently capitalist transformation in agriculture.

\section{Summing Up}

To conclude this section, the ability of the recent literature to deal realistically with the challenges of Africa's future trajectory is compromised across the board by 'Smithian' assumptions that take attention away from the critical matter of the incentives associated with prevailing social-property relations. The new interest in manufacturing as the primary locus of economic transformation has produced some work on firm types that touches on the issue without getting to the heart of the matter. The neglect of the equivalent issues in relation to agriculture and food chains is even more complete. This is serious, because the employmentintensive manufacturing and modern services that Africa needs is unlikely to develop in the absence of a productivity revolution brought about by capitalist disciplines in agriculture.

The advances and the gaps in the current thinking about Africa's development challenge obviously have much to do with the strengths and weaknesses of modern economics, the most influential discipline in development policy by far. The topic of social-property relations falls between the several stools of $21 \mathrm{st}$ century social science, illustrating one of the enduring challenges to the construction of a political economy of economic transformation. In apportioning blame for this state of affairs, however, it would be wrong to exempt political research and theorizing about states and development. To these topics I now turn.

\section{GOVERNING THE TRANSITION: CAPITALISM AND THE STATE}

Government policies are without doubt the most powerful variable affecting the ability of African economies to become more productive and innovative. The leading lights of the 'jump starting' strand of policy economics (Monga and Lin, 2015; Lin and Monga, 2017) are completely persuaded of this. Moreover, they can cite evidence in support of it. At least in the case of formal sector firms, African producers are demonstrably disadvantaged by a number of things that are in principle under government control - institutions to build inter-firm trust, infrastructure, access to finance, etc. And once these variables are controlled for, the firms do not underperform; to the contrary, they actually exhibit 'conditional advantage' in productivity levels and growth, and sales growth (Harrison et al., 2014).

The jump-starters are also convinced of the power of ideas to bring about changes in policy frameworks, a belief supported by the intellectual impact they themselves have had since their spell at the World Bank. However, they need help (as do advocates of the Kaldor/Hirschman variant - Cramer et al., 2020) in taking forward their agenda, first to understand why policy uptake of their compelling advice to the region's politicians has been patchy at best, and second to understand the broader change processes within which policies might be expected to shift in the desired directions.

If, as I have argued, 'jump-starting' policies will not work if they do not include food agriculture, and if the problems in agriculture are not just about capacities but about incentives and social-property relations, we need a political analysis agenda that targets these issues directly. In this second part of the article, I explore what that might entail. In what ways do our current ways of working on the politics and political economy of economic transformation need to be expanded and adjusted?

\section{Building on Success}

As I said at the outset, the achievements of applied politics research over the last 20 years are far from trivial. In combination with trends in heterodox economics, politics research has been spectacularly 
successful in putting the state front and center of policy-makers' frameworks. A space for political economy has been successfully carved out within economics-led institutional theory. Indicators of this success include the dedication of 56 pages of the Economic Report on Africa 2011 to 'the role of the state in economic transformation' (ECA and AU, 2011). The prominence of governance, including political settlements and conflict dynamics, in the model 'theory of change' included in the mandatory Country Development Diagnostic tool used by the UK's development assistance programmers (DFID, 2018) is also worth mentioning. Following several decades in which international development was seen primarily in terms of technology transfer, financial aid and public-sector capacity building, it is now taken for granted that the political economy of public policy is the fundamental framework in which development problems need to be addressed.

With more mixed impacts outside the academy, politics research has done a good job of clearing away the shaky intellectual foundations of exportable concepts of 'good governance'. The various bodies of work in the ESID tradition that I cited in the Introduction have taken as their common starting-point that development breakthroughs are not associated with any one regime type, in the mainstream sense of this term (democratic, authoritarian, etc.). They have gone on to offer a number of more plausible typologies of the governance of development, influenced to a greater or lesser extent by Khan's pioneering efforts to place the analysis of rents and power at the center of institutional theory (Khan, 1995; Khan and Sundaram, 2000). Their flagship publications have addressed the diversity of governance and economic growth trajectories (Levy, 2014); the commitments and capacities that matter most in different policy domains; the roles of 'Weberian' bureaucracies, on the one hand, and so-called 'weak institutions', on the other (Hickey et al., 2015; Centeno et al., 2017); and the 'deals environment' shaping growth in different economic sectors (Pritchett et al., 2017). Against this background, researchers have generated a steady flow - well beyond the referencing scope of this article - of sophisticated treatments of the political economy of a range of particular development issues, from social protection to gender inequity and from education to the management of oil and gas reserves.

In turn, the rising quantity and quality of political-economic research has stimulated and supported discussion among development assistance practitioners around the application of relevant concepts to strategy and programming. Training in applied, problem-driven political economy analysis is now provided routinely by well-established teams, including, in the UK, a partnership between staff of the Overseas Development Institute and The Policy Practice. Through these and other channels, politics and governance research has shown it can have an impact.

However, celebrating this record of achievement must not stop us recognizing gaps and suggesting new avenues for the future, especially if what is missing seems crucial, if the neglect may be increasing, and if something that was a live topic in the past has disappeared from view for less-than-sound reasons. If the argument of the first part of this article is right, there are real grounds for these concerns.

\section{The Needed Reorientation}

Cathy Boone ends her massive study of property and political order in Africa (2014) with a warning to comparative politics scholars: that by omitting property regimes from their analyses, they may be missing fundamental determinants of the outcomes of interest to them. They may be attributing election results, clientelism, ethnic politics, territorial conflicts, regime types and the strength or weakness of civil society to the wrong causes $(2014$, p. 310$)$.

This is both true and quite profound. Recent politics research has looked too narrowly within the political sphere itself for its explanations of political outcomes, referring everything back to the developmental or predatory character of the state - or, alternatively, the nature of the prevailing political settlement - failing to recognize the extent to which both the character of the state, and what the state can feasibly undertake, are shaped by certain socio-economic fundamentals.

The matter is broader than property rights and land. While land rights and claims are possibly more important than anything else, Boone's argument could well be extended to basic social relationships and livelihood transactions across the board, including, as discussed earlier, capitalist class formation and the ability or otherwise of corporate business to discipline and assist households and informal enterprises to 
close technology gaps. In the politics field, we have become accustomed in recent years to not asking research questions about how social class structures shape political patterns, enabling or constraining the real possibilities. At the same time, our interrogation of the political sphere has failed to discriminate sufficiently among the functions that states may realistically be expected to perform at different moments in the evolution of a system of social-property relations.

I want to argue, therefore, for a twofold reorientation of politics research: first, a renewal of interest in the socio-economic foundations of politics; and, second, a more refined deliberation on the 'developmental state' theme, giving much greater prominence to the matter of states' willingness and ability to promote capitalism or capitalist-driven development. Such a reorientation seems essential to a serious effort to face up to the scale of the African transformation challenge.

In spite of its solid achievements, politics research over the 20 years has helped less than it might to address the issues posed in the first part of this article. This is true, I will argue, in both a general and a more specific and qualified sense, where the more qualified argument refers to the important branch of research initiated by Mushtaq Khan and deploying the concept of political settlement.

Overall, politics research perspectives have been hindered by a focus on the state and its effectiveness - as opposed to the form of state that is typical in non-capitalist settings and the extent to which it tends to inhibit socio-economic transformation. On the one hand, there has been a tendency to replicate the error of the growth economists. That is, too many concessions have been made to the notion that Africa's states, as well as their economies, are immature or dysfunctional versions of the generic organizational form whose mature version is to be found in OECD countries, rather than a distinct variety, shaped and limited by the type of socio-economic setting in which it is embedded. On the other hand, attention has been given to effectiveness in all the areas in which modern states are expected to be effective. Priority attention has not been given to the role of power and politics in the critical field of enabling or blocking transitions to capitalist or capitalist-led social-property relations. This applies to ESID's original research vision and to that of its trans-Atlantic cousin, Centeno et al. (2017).

The more specific argument applies to the trends of thinking reflected in ESID's mature research programme centered on political settlement typologies, as well as in Khan's own work and that of his immediate followers. This is closer to the position this article is proposing, but not in all respects. Therefore, I set out the general argument at some length first and go on to show how it needs to be qualified with regards to settlements analysis.

\section{Revisiting Skocpol et al.}

In general, we have been following too closely the injunctions of the pivotal volume of 35 years ago, Bringing the State Back In (Evans et al., 1985). We have brought back the state too exclusively and need to take a step back.

The thesis advanced by Skocpol, Evans, Tilly and their colleagues in the early 1980s was a valid critique of Marxist and liberal perspectives that effectively treated the state as an epiphenomenon of societal or socio-economic processes. The move was timely and correct, including in its rejection of the Marxist version of the 'society centered' view, which had been grossly reductionist in its treatment of the variety of state forms. Skocpol (1979) was right, and an important pioneer, in arguing that major political revolutions, from 1789 onwards, were about the structure of the state, not about rising socio-economic groups. However, historians working in the broad Marxist tradition were not idle in the following years. They have done their own quite thorough job of overturning reductionist concepts like 'bourgeois revolution' and the corresponding misinterpretations of the history of France and Germany among others (Blackbourne and Eley, 1984; Comninel, 1987).

For some of those historians, the aim has been to separate the wheat from the chaff in the Marxist intellectual legacy. What they want to preserve usually includes the core of the Brenner/Wood thesis. To the extent they are right, the judgement on 'bringing the state back in' must be that it went well beyond the requirements of defeating socio-economic reductionism. It weakened to an unnecessary degree the bidirectional analytical links between understanding state structures and understanding socio-economic structures, especially social-property regimes.

Journal of Applied Business and Economics Vol. 23(3) 2021233 
This point of view has been developed a long way in the international relations (IR) field, without, as far as I am aware, any influence from or upon development studies. Teshke (2003) rejects the mainstream assumption in the IR field that its subject matter is a homogeneous field of modern states. He contests the idea that the origins of the modern state system can be traced all the way back to the treaties of Westphalia that ended the pan-European 30 Years' War in 1648. Rather, the modern state - distinguished by being a specialized organization supporting the general interests of capitalism - emerged historically in tandem with capitalist social-property relations, and not before. It emerged first in England and very much later in other European countries.

Teshke's theory, based on Brenner, is that states become specialized organizations for promoting the general interests of capitalism if and when the dominant orientation of the producing classes and their exploiters becomes radically dependent on the market - in other words, when they are no longer able to rely on either ownership of their means of subsistence or control of the means of coercion for their reproduction. Until this separation happens, states remain torn between two different roles, collaborating in extra-economic coercion and expanding, and taxing, profits and wages. The types of state we know today in OECD countries no longer face this particular dilemma. Those in most developing countries still do.

\section{The Embeddedness of the State in Society}

States in Africa are not immature or dysfunctional versions of the generic type of institution whose mature version is to be found in OECD countries. This does not mean they are all the same or that the diversity of state forms across the continent is unimportant. Nor does it imply that African state forms differ markedly from those found in other regions where capitalist social-property relations are poorly developed. Nonetheless, the generalization that state forms or public spheres are shaped in part by the societies in which they are embedded, and that African societies, in turn, have some features that set them apart in interesting ways, has not ceased to be true since this theme was first developed by writers such as Ekeh (1975), Hyden (1983), Chabal (Chabal, 1992; Chabal and Daloz, 1999), van de Walle (2001) and Kelsall (2008).

One may disagree with some of the formulations developed by this type of society-centered state theory, such as Hyden's (1983, p.19) about the economy of affection rooted in peasant society tending to 'swamp' the public realm or Kelsall's 'working with the grain'. However, bringing the state back in as a focus of systematic research did not need to imply neglect of the social underpinnings of political behavior. And there is no reason in logic why refocusing on the diversity of African experience, which has been a positive feature of recent politics research, should imply neglect of important commonalities.

The view that in order to research diversity, it is necessary to deny the pertinence of any generalizing concepts was one theme in the attacks on the concept of 'neopatrimonialism' that were a feature of Africanist political research in the first decades of the 21 st century (a literature well summarised by Gray and Whitfield, 2014, pp.4-8). Particular criticism was heaped on those versions of the concept deemed to be culturalist, implying continuities between traditional rural clientelism and modern urban clientelism. In fact, to the extent that the distinction between culture and structure makes sense, the social foundations of what is described as neopatrimonial political behavior are eminently structural. We are dealing with societies that lack the kind of intermediate organizations - civil society in the classical sense of the term that flourish in a capitalist economy and are key enablers of modern, especially liberal-democratic, state formation.

Motivated in part by discomfort with the idea of African exceptionalism, these critiques have the effect - I would argue - of placing Africa outside the mainstream of world history by implying that its political structures are somehow immune to the normal effects of absent, or near absent, rural capitalism. Historically, it is incontestable that the state under a fully developed capitalism responds to social demands in an entirely different way than states in peasant or other non-capitalist settings. It would indeed be an anomaly if Africa were not to conform to this regularity.

I suggest, therefore, that it is time for the 21 st century drive to dismiss the more sociological and more generalizing strands in Africanist scholarship to be put, at least for a while, into reverse. We need to be reminded that the lack of real rural transformation in Africa is not just important for economic reasons to 
do with jobs and the youth bulge. It is also a problem from the point of view of the chances of consolidating effective, liberal and democratic states. The transformation Africa needs will involve breaking into a circle of causation in which the socio-economic fundamentals contribute to features of the state - and the weaknesses in the leadership of public policy - that, in turn, contribute to immobility in the socio-economic realm.

\section{What Makes Regimes Developmental?}

It also needs to be recognized that our appreciation of the state's role in economic transformation remains incomplete. Despite a couple of decades of research, we are still weak on how we would recognize a developmental state in Africa if we were to meet one, and, especially, where we would expect such a state (or, better, regime) to come from.

Most research in the ESID tradition, from Khan (2010), through the Africa Power and Politics Programme (Booth, 2012; 2015), to Pritchett et al. (2017), has taken quite a narrow band of intermediate variables as critical links between the state and politics, on the one hand, and development outcomes, such as sustained economic growth, on the other. We have focused mainly on two variables: length of political horizons; and ability to deliver on commitments.

In earlier thinking about how to customize the East Asian concept of developmental state/regime for application to contemporary Africa $(2014 ; 2018)$, I proposed making space for some additional defining features, including elements of policy substance and some qualities of policy style. I argued this could be done with reasonable parsimony and without rendering the definition circular. Specifically, I proposed adding two things to long-term vision - first, a commitment to economic inclusion, via investment in smallholder agriculture and/or labor-intensive manufacturing, and, second, the problem-driven learning suggested as a genuine universal by Ohno and Ohno (2012) and Oqubay and Ohno (2019) as well as by the Harvard state-capability group (Andrews, 2013; Andrews et al., 2017) and, on China, by Ang (2016).

This now seems insufficient. We have overlooked the obvious factor of the regime's posture towards capitalism. Surely, a common feature of developmental regimes is that they are both in principle and in practice favourable to the entry of capitalist firms, as actors or drivers, into crucial production or productionsteering processes. Developmental regimes facilitate the entry of capital into the sphere of production, not just trade. Policies on direct investment by foreign firms vary, of course, but not attitudes to capitalist involvement as such. This is supported by the evidence not only on successful Asian regimes but also on those early-independence regimes in Africa that inspired the hypothesis of 'developmental neopatrimonialism' (Kelsall, 2011; 2013) - Côte d'Ivoire under Houphouët-Boigny, Kenya under Jomo Kenyatta and Malawi under Kamuzu Banda.

My own thinking about the case of Rwanda has arrived at belated recognition of this principle. In our first studies of Rwanda, Golooba-Mutebi and I $(2012$; 2014) stressed the way the prevailing political settlement favors coherent implementation of a long-term development vision, contrasting with the modal pattern across the region. We underplayed the observation that the government's posture towards private firms, local and foreign, has proven ambivalent - too easily overridden by other priorities - numerous examples of which have been provided by Behuria (Behuria, 2015; Behuria and Goodfellow, 2018; Behuria, 2020) and Mills (2010, pp. 175-181). We also came slowly to recognize the lack in Rwanda of a robust commitment to an employment-intensive growth path and a structured process for 'failing fast' and avoiding repetition of major policy mistakes (Booth et al., 2018), the latter being another strong theme in Behuria's work (2018b; 2018a).

It follows from the general argument that one of the most important distinctions to be made among regimes in Africa is between those that are interested in kick-starting economic transformation with efforts to facilitate the entry of capital into promising sectors, including agriculture, and those that are not. The reason why so many countries in Africa find this difficult is not that they are badly governed in a general sense - though they may be. It is because their leaders are ambivalent about capitalism. Most current regimes are committed in principle to 'private sector development'. Few, if any, are interested in assisting at the birth of a new set of social-property relations, and facing up to the nationalist, ethno-sectarian and other dilemmas that this is likely to entail. 
Linking back to my earlier argument, the reasons for this ambivalence may be partly ideological and partly based on political risk-aversion. But they surely also include the fact that politics in the country is embedded in a fundamentally non-capitalist social and economic system, responding to the incentives and social accountabilities that are features of such systems.

\section{The Right Learning From East Asia}

Globally, since the largely unintended British 18th-century economic breakthrough, developmental 'catch up' has tended to be purposeful and actively steered, led by political regimes motivated by nationalist concerns, including preparedness for war. Pressures on the state from incipiently capitalist civil societies have not usually been the critical factor, one of the things that Evans et al. (1985) were right to stress. The arguments of Doner et al. (2005) on the role of strategic challenges and shocks in the genesis of Asian developmental states have deepened this way of thinking about the likely sources of elite motivation for development elsewhere in the world. The implications have usually seemed depressing in the African context, given the region's otherwise fortunate ability to avoid, for the most part, major inter-state rivalries and conflicts. However, the dominance of this theme may have led us to neglect a topic that is at least equally important; that is, the ability of one thing to lead to another in unanticipated ways.

This is the central thesis of an important and unduly neglected book comparing development trajectories in a number of countries of East Asia and Latin America (Davis, 2004). Davis argues that the most famous feature of the South Korean development model, the extraordinary growth of industrial chaebols, was the unintended consequence of early efforts by President Park Chung Hee to foster rural development and, particularly, the formation of a rural middle class. The export orientation did not arise from a technically expedient calculation by a state elite that knew in advance how it would contribute to national development. Rather, the early adoption of the policy of forcing industrial firms to export was a means to the end of promoting capitalism (or, as Davis prefers, middle-class development) in the countryside. It was meant both to dampen urban consumption of manufactures deemed to be luxuries, and to earn foreign exchange for investment in rural infrastructure. Thus, the fully-fledged post-1974 industrialization strategy was arrived at almost by accident. It was the product of serendipity rather than strategic calculation, for much of the time at least (ibid., pp. 150-157).

Davis' argument about Korea suggests new ways of thinking about developmental state possibilities in Africa. Her broader thesis, derived from the country comparisons, is that the embeddedness of regimes and their ideologies in rural middle-class development does not just help in achieving strong backward and forward linkages between agriculture and industry. It is also a factor in the willingness and ability of regimes to impose performance standards on capital and labor (ibid., p. 247) - in other words, to set about facilitating the emergence of fully capitalist social-property relations in the manufacturing sector.

Other parts of the literature on Korea support the idea that the policies of the Park regime can reasonably be portrayed as giving birth to capitalism. Historians of the colonial era trace the origins of industrial capitalism to Japanese policies, including the unleashing of agrarian tenancy conflicts that induced some landlords to transfer their capital off the land (Shin, 2006). However, in the context of the post-war South, Kim and Leipziger (1997) write:

'For many centuries, Korea was not a country in which entrepreneurship thrived ... To be sure, some Korean businessmen had managed to get rich during the period of reconstruction [but] they were all suspected of having made their money through illegal means such as bribery' (ibid., pp. 197-198).

In many respects, Park created the country's industrial capitalist class. Having at first signed arrest orders for a large group of plutocrats, including the founder of Samsung, the government came to recognize the need for a class of real entrepreneurs, and set about creating one, getting closely involved with business itself, creating incentives, distributing prestige-building prizes and medals, and sharing risks with private firms. Studwell (2013, pp. 84-104) provides further details. 


\section{What's New? 1: North, Acemoglu and Company}

My argument, then, is that future research on the political economy of economic transformation in Africa should take as a priority topic the exploration of how political regimes might overcome their ambivalence about capitalism, and thereby become amenable to the much-improved advice that economists are now offering. I am not aware of any current research programme that addresses this question directly.

It might seem that some aspects of it at least have been covered in the quite extensive institutionalist literature of the last 20 years. For example, how does my argument relate to the authoritative works of North et al. (2009; 2013), Acemoglu and Robinson (2012) and especially Khan (2010; 2018)? For sure, all have been centrally concerned with affinities and interlinkages between political institutions and power structures, on the one hand, and markets and economic rents, on the other. And Khan, as we saw earlier, takes as his starting point the same critique of the Smithian mainstream that informed the first part of this paper. However, the linkage stories provided by North et al. and by Acemoglu and Robinson are to different degrees incomplete and unsatisfying. And while Khan and his followers are much closer to the position of this article, their framework concept - the political settlements typology - steers them away from an adequate response to the Brenner problem in Africa. Let us consider the mainstream institutionalists first and then Khan and his followers separately.

The North et al. (2009) concept of 'access' (limited or closed) explores affinities between competitive political arrangements and competitive economies. Its description of the transition from a limited access order to open access order illustrated by the experience of three first-mover countries (Britain, the USA and France) is of real interest. Its useful insights include this Teschke-esque gem:

'The separation of military, political, and economic interests and organizations is ... not a natural outcome in human societies but the result of a very special set of conditions ... It is only when the goose that lays the golden egg is not owned by a hapless peasant or powerless non-elite, but a strong and well-organized economic specialist, that a credible commitment not to use violence can produce sustained commitment to governmental policies that promote economic security' (North et al., 2009, p. 175).

More generally, the description illustrates how the growth of openness in the political and economic spheres is cumulative and self-reinforcing. A common feature across the cases is growing elite interest in creating more widely applicable rights and more impersonal types of organization as economic development proceeds.

The analysis is accompanied by appropriate cautions about generalizing from the first-mover experiences. In the subsequent edited volume (North et al., 2013), the concepts are shown to be applicable to several developing or emerging economies. However, the theory remains quite thin on causes and drivers, these being seen as specific to each society. Hence, it adds little to understanding of the state-formation processes and conflicts among and between dominant and other class interests that have been invoked in other literatures to explain the institutional outcomes (and their unevenness between the cases). In the final analysis, the account is less enriching as an aid to thinking about transition issues in Africa than the Brenner/Teschke version, because it says little about how similar change processes in other settings might get started.

Acemoglu and Robinson's (2012) concept of extractive versus inclusive institutions similarly highlights interdependencies between political and economic spheres. Their broad-brush conceptualization seems vindicated by some striking stories of path dependency. They succeed in showing, in a number of instances, how initially small differences in institutions and power structures between otherwise comparable societies at critical junctures turned progressively into large differences that had crucial effects on longterm performance. Together with their previous econometric studies comparing 'settler' and 'non-settler' paths of development in the Americas (Acemoglu et al., 2001), their book has become a standard citation in support of liberal-democratic governance reforms in Africa. The implication is that 'nations fail' because they have the wrong institutions, inviting the conclusion that reform of economic and political institutions is a sound starting point. 
The earlier work was roundly criticized for misrepresenting some key historical sequences. The establishment of successful capitalist economies with 'inclusive' institutions in the British settler colonies of North America followed and was dependent upon the systematic and violent destruction of the preexisting property rights of the native populations (Khan, 2012a, pp. 68-72). The book has more to say about power, including the capacity for violence. It suggests that the balance of forces, between groups, by affecting the ability of the powerful to impose 'extractive' arrangements, is a crucial determinant of institutional choice. It is, however, open to another serious objection.

This is that the selection of particular path dependencies for attention is heavily skewed towards two extremes, to the almost complete neglect of developing Asia, where the indicated affinities are much less apparent. The hypothesized links between liberal democracy and inclusive economic development break down completely in the authors' efforts to make sense of China. The book therefore provides a seriously incomplete account of what is known about how nations succeed or fail.

\section{What's New? 2: Political Settlements Analysis}

In the case of Khan, the question 'what's new?' is less straightforward, partly because his theory has marxisant origins. Khan's starting position is similar to the one advanced in this paper, as recognized earlier. I would argue, nonetheless, that the evolution of his thinking about political settlements has moved his work, and that of his substantial group of followers, away from what I am arguing is a central question for the future of Africa.

It might seem that the conceptual difference is only one of language. Khan's 'organizations', whose power and rent bargains are at the center of his political settlement construct, are so named partly in a conscious effort to avoid the reductionism of 1970s and 1980s Marxism - e.g. Hamza Alavi's (1972) analysis of Pakistan and Bangladesh - where the dominant political actors were taken to be either social classes, defined in terms of a relation to the means of economic production, or actors on behalf of classes (or class fractions). The anti-reductionist intent is commendable, as it was in Skocpol (1979), but this has come at the cost of explicit recognition that, at a certain analytical level (not, it should be said, the level of rent bargaining and political action around industrial policy) social class structure remains fundamental to Africa's transformation challenge.

The loss of this focus is especially significant in the context of Khan's most influential contribution, his typology of political settlements. In the pivotal paper (2010), Khan builds his typology in three steps, each informed by a two-by-two matrix of defining features. In Step 1, the variables are i) whether the 'holding power' of organizations is based primarily on formal institutions (i.e. rules) or not, and ii) whether the formal institutions are 'growth enhancing' or not. We get three stable types of political settlement:

- The capitalist type, 'where holding power is (to a large extent) aligned with formal rights and institutions, and the latter largely define productive capitalist property rights';

- A very broad group of clientelist political settlements, where 'significant sources of holding power are not aligned with formal institutions'; and

- Pre-capitalist political settlements, where power 'was aligned to a much greater extent with formal institutions but these institutions were generally non growth-enhancing' (ibid., pp. 47, 48).

In quite a casual way, Khan identifies the middle category with 'contemporary developing countries' while the third is associated narrowly with variants of feudalism, 'with formal land and military rights aligned with distributions of political-military power' (ibid, p. 48). Thereafter, the typological effort concentrates exclusively on variants of clientelist settlement, generating, as Step 2, the influential fourcategory typology based on vertical and horizontal power distributions among factions of ruling coalitions.

Social-property relations enter the picture to a certain extent in Step 3, where it is acknowledged that the strategies that ruling coalitions can follow, and their likely effects, are constrained by the capabilities and organization of productive entrepreneurs or emerging capitalists in a given country. Here the two variables are the technological and entrepreneurial capabilities of domestic firms on the one hand, and their holding power within the networks of the clientelist settlement on the other (ibid., pp. 67-72). 
Khan's analytical choices can be justified in terms of the support they give to his generally compelling account of the success and failure of industrial policies (meaning, here, policies for manufacturing) in Asia, Latin America and Africa. However, they make much less sense in relation to the fundamental challenges facing sub-Saharan Africa at this moment. To begin with, most of the region should properly be treated as having a pre-capitalist type of settlement, to the extent that the formal as well as the informal institutional rules around its 'uncaptured peasantry' are largely non-capitalist and, in Khan's terms, not growthenhancing. The problem is not that there is misalignment between the power structure and the formal institutions, the distinguishing feature of clientelist settlements.

To be sure, the African rural scene is not feudal either, but Khan's reduction of pre-capitalism to feudalism is gratuitous, as is his generalization that all developing countries fall squarely into the category of clientelist settlements. The category of pre-capitalism is unfortunate for other reasons, tending to imply some teleology of historical stages. Non-capitalist is a preferable term. And, finally, Khan's treatment of domestic capitalists in Step 3 suffers from the same limitation that I (with his support) tasked the mainstream literature on entrepreneurship. That is, it focuses on the technological, business and politicalorganizational capabilities of firms, taking for granted the more basic historical challenge of freeing the organization of productive investment from the shackles of the subsistence-oriented household and the economy of affection.

Khan's followers include some of the best researchers on the topics of concern to this article, and their work has already been cited in several places for this reason. As well as containing some of the clearest exegesis of the fundamentals of the approach (e.g., Gray and Whitfield, 2014; Behuria et al., 2017), their work gives us material for thinking through the limitations that current political settlement frameworks have when it comes to handling the breakthrough that Africa most urgently needs.

Hazel Gray maintains (2018, pp. 60-61) that Khan's framework is the legitimate successor to Brenner, in the sense that both center on power struggles around property rights as the fundamental enabler of capitalist economic transformation. However, the legitimacy of this succession is questionable for two reasons.

First of all, the outcome of interest has shifted in a crucial way. Khan's framework is certainly interested in economic transformation and is a major contribution to the increasingly sophisticated treatment of industrial policy that was the subject of the first pages of this article. It is less clear that it is centrally concerned with the establishment of capitalism, because it is assumed that capitalist social-property relations already have a significant foothold in most African countries and have done so since the colonial era. 'Capitalism exists across much of Africa, in the classical Marxist sense where capitalism is identified in terms of the underlying mode of production' according to Gray and Whitfield (2014, p. 12). ${ }^{7}$ For them, it is only the political settlement that is not capitalist. Attention therefore shifts to whether the available financial resources, including the fruits of the 'primitive accumulation' of recent decades, can find their way into productive investments, especially in large-scale manufacturing (Gray and Whitfield, 2014, pp. 13-15, 21-22).

Directing finance into manufacturing and other globally oriented production is an important topic but it is premature to give it exclusive attention. This is shown clearly by Gray's own detailed analysis of the case of Tanzania $(2018$, p. 21$)$. In that account, a fundamental reason why Tanzania has done so much less well in economic transformation than Vietnam is that productivity in food agriculture has remained low, leading to real wage rates that make the country uncompetitive in manufacturing and other world-market production.

Secondly, Khan's typology serves well enough as a way of distinguishing patterns of clientelism across countries, which provides important background for any analysis of policies and outcomes. It serves this purpose in Khan's own country work and those of his followers writing on Ghana and Tanzania, as well as the range of excellent studies sponsored by ESID. The same purpose is met, arguably even better, by Tim Kelsall's revised version of the approach (Kelsall, 2018a; 2018b). This adopts the same two-dimensional method of typology construction, while keeping closer to the original idea of a 'settlement' between otherwise violently conflictual interests. However, as ESID research has confirmed, the location of a prevailing settlement within a two-dimensional scheme only explains outcomes in a rather basic way and 
in certain sectors of development activity. Proponents of the approach (e.g. Whitfield et al., 2015) admit that many of the determinants of progress in economic transformation are sectoral. And in some of their own country work, the main explanatory work is done by factors that are not central to the framework.

Thus, Whitfield's mature work on sectors in Ghana, especially horticulture (Whitfield, 2018, Ch. 5-6) leans heavily on concepts from new institutional economics and collective action theory to explain outcomes that are not fully accounted for by the standard political settlement variables. Whitfield's concluding plea (pp. 309-328) for the adoption of modern industrial policy principles hinges on Ghana's leaders' overcoming their deep hostility to the foreign direct investment needed to build local capitalist capabilities in a world of global value-chains. This, in the final analysis, is the topic that calls for more political debate and further research. It is much closer to the central proposition of this article than might appear from some of the more programmatic claims on behalf of political settlements theory.

Similarly, in her treatment of the barriers to capitalist development in Tanzania's agriculture, Gray (2018) makes little use of the variables she has used to place Tanzania in relation to Vietnam in the book, or in relation to other African countries elsewhere (2013). Instead, she gives a persuasive account of how political leaders at different levels have consistently acted to block any green shoots of capitalist socialproperty relations (pp. 143-153). At a fundamental level, it could be argued, this reflects the attitudes of a class that that does not need to engage in, or provide support to, capitalism in the countryside because it has adequate extra-economic levers with which to secure its domination. In contrast, Vietnam (pp. 153-162) followed other East Asian countries in establishing and maintaining a very close relationship between smallholders and state agencies, providing elements of both active support and discipline - the functional equivalent of a capitalist agrarian transition.

African politicians who are fearful of African entrepreneurs is a theme in the historical overview by Gray and Whitfield (2014, p. 25) as well as in other historical surveys (Handley, 2008; Kelsall, 2013). As we have seen, Behuria's work on Rwanda has brought this theme to the fore in developmental state literature. In their conclusion, Gray and Whitfield also call for more research on whether and how agrarian capitalism may be emerging in unprecedented ways, including through investment by urban businesses and foreign firms $(2014$, p. 28$)$. This is more or less identical to the argument of the present article, if it is added that analysis and debate should be focused on the political-economic conditions that might induce such changes. Putting this at the center of the research agenda would nonetheless involve different research priorities than suggested by the political settlements typology itself.

The bottom line is that, along with much other research on the politics of development since the 1980s, political settlements analysis has pushed a little too much theoretical attention onto the specifically political level of analysis, leading to neglect of matters that are deeper and more sociological in character.

\section{Summing Up}

To summarize, since the 1980 s we (those working in the ESID tradition) have bought in too comprehensively to the notion that our subject matter is a homogeneous field of modern states. The relationship between the state and changes in the relations of production needs to come back into the center of the picture. This is for two reasons. One, our expectations of states and regimes should be tempered by an understanding of the context in which they operate. And two, we should be giving considerably greater priority to exploring how political and social changes leading to the advent of capitalism in Africa might come to pass as a result of changes in political direction. Despite the considerable advances that have been made in political economy analysis, not least under the umbrella of political settlements theory, we need a new framing that forces us to address this, the central economic and political challenge affecting the future of Africa in the world.

\section{CONCLUSIONS AND IMPLICATIONS}

Sub-Saharan Africa faces large questions about its future, to which few countries, if any, have answers. This is, in turn, one of the biggest long-term issues for the future of the world. In theory, this paper has argued, we are closer to the necessary understanding of what needs to be done than we were 20 years ago. 
The difference between economic growth and economic transformation is now central to the framing of policy priorities. The capacities of firms and innovation systems, previously central to the special field of industrial policy, have moved into the mainstream of policy economics and have helpfully been joined up with updated structuralist trade theory, generating clear and potentially persuasive messages for countries' political leaders. However, this improved consensus falls down in handling the rural and agricultural side of economic transformation, a precondition for the manufacturing-centered remedies to begin to work. One reason for this is that agricultural transformation is not just about markets and capabilities but also depends on the fundamental incentive structures generated by prevailing social-property relations, a topic that economists in all of the traditions stemming from Adam Smith have difficulty handling.

It seems unlikely that future generations of Africans will get the employment-intensive development they need without further efforts to bring capitalism to the countryside. That may and may not mean major consolidation of land ownership (the case for large farms, as such, has not been established, pace Cramer and colleagues) but it does imply bringing the more capable smallholders firmly under the control of the corporate businesses that have the technological and management capabilities (and motivations) to transform productivity. In turn, this means renewing the historically informed habit of mind that is at the core of traditional Marxist accounts of agrarian transition, in which social pain and social progress are seen as intertwined - a point eloquently made by Graham Harrison (2016) in the context of refusing to pre-judge the outcomes of current agrarian policies in Rwanda, and again by Cramer et al. (2020) on a more continental canvas.

The gaping hole in the recent economic policy consensus is also a weakness in the way we are currently framing priorities for political and political economy research. This is critical because the obvious ways forward - such as investments by corporate capital in raising the productivity of small and medium farms with modern production technologies and logistics - will only crack the fundamental incentive problems, and add up to a change in social-property regime, if they include rigorous enforcement of contracts. Enforcement is a very political matter. Political leaderships across Africa typically baulk at enforcing anything on smallholders, and this reflects in part the fact that they themselves are products of the current social-property regime, not the regime of the future. Therefore, finding a way of breaking into the perverse circle of causation between near-absent rural capitalism and the political behaviors typical of societies in which capitalist social-property relations are not yet dominant is, or ought to be, the number-one question for anyone concerned about African futures.

As always, translating a question about the future into a research agenda is tricky, because it is only possible to do empirical work on that which exists or has existed. We clearly do need more and better empirical work on what is happening on the ground currently. A part of this should be the type of work on domestic capitalists initiated by Behuria (2019) and Staritz and Whitfield (2017), and the kinds of rural micro-studies undertaken by Ponte and Brockington (2020). But we also need a new steering framework and more definite theoretical priorities.

Over the last 20 to 40 years, we have been steered a little too simply by a certain understanding of the implications of East Asian development success. While the benefits of looking to Asia have been massive, we have 'brought the state back in' in a way that has generated losses as well as gains. We have been influenced too much by the 'heroic' phase of South Korean development and by matters of industrial policy, understood as policy for manufacturing. We swallowed too easily the story about the importance of strategic political vision, neglecting the earlier history when other necessary conditions were created. The Mushtaq Khan political settlements framework, in particular, needs to be revisited. While much of the best work of direct relevance to our priority theme has been done by adherents of Khan's framework, the framework itself is too heavily oriented towards explaining diverging industrial-policy outcomes, understood in this narrow sense. It is flawed by its initial assumption that the problem of getting capitalism started in agriculture has already been solved.

The gains from typological theorizing about political settlements have been considerable, especially compared with previous approaches centered on degrees of democracy. We need now to build on what has been gained, focusing on the outcome variables and drivers that are going to be most central to the future trajectory in Africa. This means a fresh approach to what we should be looking for in any African 
'developmental state', downgrading the themes of long-term vision and comprehensive implementation capacity, and giving greater priority to the willingness and ability to get capitalism into agriculture.

We should also take account of Davis's other corrections to the received story about South Korea. The politics that Africa's economic transformation requires may not come from an expected source or in an obvious form. Visionary leadership, pursuing strategic goals defined by technocrats, is a possible pathway, but we should also be open to more indirect routes. In our political economy, there needs to be room for serendipity as well as for sober realism.

\section{ACKNOWLEDGEMENTS}

Drafts of this article were presented at ESID's concluding conference in 2019 and appeared in the programme's Working Paper series as No. 163/2020. I remain grateful for the generous comments made by ESID colleagues and referees.

\section{ENDNOTES}

1 I have in mind the research programmes whose findings were summarized in Future State (2005), Moore and Unsworth (2010), IPPG (2010), Khan (2010), Putzel and Di John (2012), Booth (2012; 2015), Levy (2014), Whitfield et al. (2015), Andrews et al. (2017) and Hudson et al. (2018) as well as, of course, Hickey et al. (2015) and Pritchett et al. (2017).

2 The current scene is not completely without encouraging signs. Well-known survey evidence from Tanzania on Micro, Small and Medium Enterprises (MSMEs) suggests there is a considerable productivity overlap between 'formal' and 'informal' household businesses, including in manufacturing. Moreover, there is a category of small firms (15 percent of the total) whose labor productivity exceeds economy-wide manufacturing labor productivity. However, the potential of these operations is untapped as a result of indiscriminate public support to MSMEs and the near absence of more targeted operations through the banking system or public-private partnerships (McMillan et al., 2017a; Diao et al., 2019).

3 Some of the analytically most ambitious of recent studies of African development (e.g., Whitfield et al., 2015; Gray, 2018; Whitfield, 2018) have embraced these ideas in the framework of versions of Mushtaq Khan's (2010; 2018) political settlements approach. However, as I argue later, one effect of the political settlements framing has been to push the central issue in agricultural transformation to the margins.

4 I believe this can and should be admitted without embracing the concerns of the wider field of neo-Marxist agrarian studies as reflected in, for example, Akram-Lodhi and Kay (2010a; 2010b). As a whole, this body of work is less committed to the standard methods of comparative history, and remains more shackled to various forms of teleology or functionalism, than the studies cited. As I argued back in 1985, Marxist metatheory seriously compromises the ability of its adherents to contribute anything useful to current policy thinking, even when conducting original empirical work (Booth, 1985). My main mistake in that contribution was to treat the 'Brenner thesis' as a mere footnote to one of the main strands of teleological thinking in fashion at that time, rather than as an exemplary exception to that approach.

5 Elsewhere, Khan emphasizes the way non-settler colonial rule 'created a multitude of rights and social entitlements that were inappropriate for asset reallocations and for creating the productivity compulsions necessary for driving growth' (2012a, p. 73). He makes a strong case for state-led non-market asset transfers to overcome the otherwise prohibitive transaction costs of acquiring land for investment in regions such as Africa (Khan, 2012b, pp. 176-178). As we see later, this position is pushed into the margins in his most influential work on political settlements.

6 Some readers will recall that what I am calling a blind spot here reflects a very long-running difference of opinion among those acknowledging Marx on the origins of capitalism, between those following Warren (1980) and Sender and Smith (1986), for whom wage labor is the conceptual anchor, and those following Brenner and Wood, who focus on the extent to which producers (households or firms) are entirely dependent, directly or indirectly via rent demands, on the market for their reproduction.

7 The authors do not explain which of the classical Marxist criteria for assessing the extent of capitalism are used here. 


\section{REFERENCES}

Acemoglu, D., \& Robinson, J.A. (2012). Why Nations Fail: The Origins of Power, Prosperity and Poverty. London: Profile Books.

Acemoglu, D., Johnson, S., \& Robinson, J.A. (2001). The colonial origins of comparative development: An empirical investigation. American Economic Review, 91(5), 1369-1401.

ACET. (2014). African Transformation Report 2014: Growth with Depth. Accra: African Center for Economic Transformation.

ACET. (2017). African Transformation Report 2017: Agriculture Powering Africa's Economic Transformation. Accra: African Center for Economic Transformation.

AfDB. (2016). Jobs for Youth in Africa: A Strategy for Creating 25 Million Jobs and Equipping 50 Million Youth 2016-2025. Abidjan: African Development Bank Group.

AfDB. (2017). Part II: Entrepreneurship and industrialisation. In AfDB (Ed.), African Economic Outlook 2017 (pp. 154-240). Abidjan: African Development Bank Group/OECD Development Centre/UNDP.

AfDB. (2019). Chapter 2: Jobs, growth, and firm dynamism. In AfDB (Ed.), African Economic Outlook 2019 (pp. 45-74). Abidjan: African Development Bank Group.

AGRA. (2019). Africa agriculture status report 2019: The hidden middle - A quiet revolution in the private sector driving agricultural transformation. Nairobi: Alliance for a Green Revolution in Africa.

Akram-Lodhi, A.H., \& Kay, C. (2010a). Surveying the agrarian question (Part 1): Unearthing foundations, exploring diversity. Journal of Peasant Studies, 37(1), 177-202.

Akram-Lodhi, A.H., \& Kay, C. (2010b). Surveying the agrarian question (Part 2): Current debates and beyond. Journal of Peasant Studies, 37(2), 255-284.

Alavi, H. (1972). The state in post-colonial societies: Pakistan and Bangladesh. New Left Review, 74.

Altenburg, T. (2018). Project proposal: African perspectives towards 2050. Bonn: German Development Institute.

Altenburg, T., \& Lütkenhorst, W. (2015). Industrial Policy in Developing Countries: Failing Markets, Weak States. Cheltenham, UK: Edward Elgar.

Altenburg, T., Kleinz, M., \& Lütkenhorst, W. (2016). Directing structural change: From tools to policy. Discussion Paper 24/2016. Bonn: German Development Institute.

Amoako, K.Y. (2011). Transforming Africa - Start now, we can't wait. African Business, 45(377), $24-27$.

Amsden, A.H. (1988). Taiwan's economic history: A case of étatisme and a challenge to dependency theory. In R.H. Bates (Ed.), Toward a Political Economy of Development: A Rational Choice Perspective (pp. 142-175). Berkeley, CA: University of California Press.

Andrews, M. (2013). The Limits of Institutional Reform in Development: Changing Rules for Realistic Solutions. Cambridge, UK: Cambridge University Press.

Andrews, M., Pritchett, L., \& Woolcock, M. (2017). Building State Capability: Evidence, Analysis, Action. Oxford: Oxford University Press.

Ang, Y.Y. (2016). How China Escaped the Povery Trap. Ithaca, NY: Cornell University Press.

Barrett, C.B., Christiaensen, L., Sheahan, M., \& Shimeles, A. (2017). On the structural transformation of rural Africa. Policy Research Working Paper 7938. Washington, DC: World Bank Group.

Behuria, P. (2015). Between party capitalism and market reforms: Understanding sector differences in Rwanda. Journal of Modern African Studies, 53(3), 415-450.

Behuria, P. (2018a). Examining effectiveness and learning in Rwandan policymaking: The varied outcomes of learning from failure in productive sector policies. Journal of International Development, 30(6), 1023-1043.

Behuria, P. (2018b). Learning from role models in Rwanda: Incoherent emulation in the construction of a neoliberal developmental state. New Political Economy, 23(4), 422-440. 
Behuria, P. (2019). African development and the marginalisation of domestic capitalists. ESID Working Paper 115. Manchester: Effective States and Inclusive Development Research Centre, The University of Manchester.

Behuria, P. (2020). The domestic political economy of upgrading in global value chains: How politics shapes pathways for uppgrading in Rwanda's coffee sector. Review of International Political Economy, 27(2), 348-376.

Behuria, P., \& Goodfellow, T. (2018). The disorder of "miracle growth" in Rwanda: Understanding the limitations of transitions to open ordered development. In L. Pritchett, K. Sen, \& E. Werker (Eds.), Deals and Development: The Political Dynamics of Growth Episodes (pp. 216-249). Oxford: Oxford University Press.

Behuria, P., Buur, L., \& Gray, H. (2017). Research note: Studying political settlements in Africa. African Affairs, 116(464), 508-525.

Berman, B., \& Leys, C. (Eds.). (1994). African Capitalists in African Development. Boulder, CO: Lynne Rienner.

Berry, S. (1993). No Condition is Permanent: The Social Dynamics of Agrarian Change in sub-Saharan Africa. Madison, WI: University of Wisconsin Press.

Blackbourne, D., \& Eley, G. (1984). The Peculiarities of German History: Bourgeois Society and Politics in Nineteenth-century Germany. Oxford: Oxford University Press.

Boone, C. (2003). Political Topographies of the African State: Territorial Authority and Institutional Choice. New York: Cambridge University Press.

Boone, C. (2014). Property and Political Order in Africa: Land Rights and the Structure of Politics. New York: Cambridge University Press.

Booth, D. (1985). Marxism and development sociology: Interpreting the impasse. World Development, 13(7), 761-787.

Booth, D. (2012). Development as a Collective Action Problem: Addressing the Real Challenges of African Governance. London: ODI/Africa Power and Politics.

Booth, D. (2014, November 20-22). Towards a developmental state concept that is fit for purpose (in the 21st century, in Africa). Paper presented at the African Studies Association Annual Meeting, Indianapolis.

Booth, D. (2018). Towards “developmental regimes” in Africa. In M.L. Bishop \& A. Payne (Eds.), SPERI Paper 43: Revisiting the Developmental State (pp. 14-16). University of Sheffield: Sheffield Political Economy Research Institute. Retrieved November 30, 2020, from http://speri.dept.shef.ac.uk/wp-content/uploads/2018/11/SPERI-Paper-No.-43-Revisiting-thedevelopmental-state.pdf

Booth, D. (2019). Striving to Transform Tanzania's Cotton Sector: Lessons from Gatsby's Successes and Failures. London: Overseas Development Institute.

Booth, D., \& Golooba-Mutebi, F. (2012). Developmental patrimonialism? The case of Rwanda. African Affairs, 111(444), 379-403.

Booth, D., \& Golooba-Mutebi, F. (2014). Policy for agriculture and horticulture in Rwanda: A different political economy? Development Policy Review, 32(s2), 259-272.

Booth, D., Calabrese, L., \& Golooba-Mutebi, F. (2018). Kick-starting economic transformation in Rwanda: Four policy lessons and their implications. Briefing Paper. London: Overseas Development Institute, Supporting Economic Transformation (SET) programme.

Booth, D. (Ed.). (2015). Developmental Regimes in Africa: Synthesis Report. London: Overseas Development Institute.

Breisinger, C., \& Diao, X. (2008). Economic transformation in theory and practice: What are the messages for Africa? RrSAKSS Working Paper 10. Washington, DC: International Food Policy Research Institute.

Brenner, R. (1977). The origins of capitalist development: A critique of neo-Smithian Marxism. New Left Review, (104), 25-92. 
Brenner, R. (1985a). Agrarian class structure and economic development in pre-industrial Europe. In T.H. Aston \& C.H.E. Philpin (Eds.), The Brenner Debate: Agrarian Class Structure and Economic Development in Pre-industrial Europe (pp. 10-63). Cambridge, UK: Cambridge University Press.

Brenner, R. (1985b). The agrarian roots of European capitalism. In T.H. Aston \& C.H.E. Philpin (Eds.), The Brenner Debate: Agrarian Class Structure and Economic Development in Pre-industrial Europe (pp. 213-327). Cambridge, UK: Cambridge University Press.

Brenner, R. (1986). The social basis of economic development. In J. Roemer (Ed.), Analytical Marxism (pp. 23-53). Cambridge, UK: Cambridge University Press/Editions de la Maison des Sciences de l'Homme.

Brenner, R. (2007). Property and progress: Where Adam Smith went wrong. In C. Wickham (Ed.), Marxist History-writing for the Twenty-first Century (pp. 49-111). Oxford: Oxford University Press for The British Academy.

Burmeister, L.L. (1990). State, industrialization and agricultural policy in Korea. Development and Change, 21, 197-223.

Burmeister, L.L. (2006). Agricultural cooperative development and change: A window on South Korea's agrarian transformation. In Y-S. Chang \& S.H. Lee (Eds.), Transformations in Twentieth Century Korea (pp. 64-85). London: Routledge.

Byamugisha, F.F.K. (2013). Securing Africa's Land for Shared Prosperity: A Program to Scale Up Reforms and Investments. Washington, DC: World Bank and Agence Française de Développement.

Byres, T.J. (1996). Capitalism from Above and Capitalism from Below: An Essay in Comparative Political Economy. London: Palgrave Macmillan.

Byres, T.J. (2009). The landlord class, peasant differentiation, class struggle and the transition to capitalism: England, France and Prussia compared. Journal of Peasant Studies, 36(1), 33-54.

Centeno, M., Kohli, A., \& Yashar, D.J. (Eds.) (2017). States in the Developing World. Cambridge: Cambridge University Press.

Chabal, P. (1992). Power in Africa: An Essay in Political Interpretation. London: Macmillan.

Chabal, P., \& Daloz, J-P. (1999). Africa Works: Disorder as a Political Instrument. London: James Currey.

Cimoli, M., Dosi, G., \& Stiglitz, J.E. (Eds.). (2009). Industrial Policy and Development: The Political Economy of Capabilities Accumulation. Oxford: Oxford University Press.

Cirera, X., \& Maloney, W.F. (2017). The Innovation Paradox: Developing-country Capabilities and the Unrealized Promise of Technological Catch-up. Washington, DC: World Bank Group.

Clapham, J.H. (1968). The Economic Development of France and Germany 1815-1914 (Fourth Edition). Cambridge: Cambridge University Press.

Collier, P., \& Dercon, S. (2014). African agriculture in 50 years: Smallholders in a rapidly changing world? World Development, 63, 92-101.

Comninel, G.C. (1987). Rethinking the French Revolution: Marxism and the Revisionist Challenge. London: Verso.

Cramer, C., Di John, J., \& Sender, J. (2018). Poinsettia assembly and selling emotion: High value agricultural exports in Ethiopia. AFD Research Paper Series 2018-78. Paris: Agence Française de Développement.

Cramer, C., Sender, J., \& Oqubay, A. (2020). African Economic Development: Evidence, Theory, Policy. Oxford: Oxford University Press.

Cusolito, A.P., \& Maloney, W.F. (2018). Productivity Revisited: Shifting Paradigms in Analysis and Policy. Washington, DC: World Bank Group.

Davis, D.E. (2004). Discipline and Development: Middle Classes and Prosperity in East Asia and Latin America. Cambridge: Cambridge University Press.

DFID. (2018). Country development diagnostic. London: UK Department for International Development (internal). 
Diao, X., Kweka, J., \& McMillan, M. (2019). Economic transformation in Africa from the bottom up: New evidence from Tanzania. In C. Monga \& J.Y. Lin (Eds.), The Oxford Handbook of Structural Transformation (pp. 619-631). Oxford: Oxford University Press.

Dinh, H.T., \& Clarke, G.R.G. (Eds.). (2012). Performance of Manufacturing Firms in Africa: An Empirical Analysis. Washington, DC: World Bank.

Doner, R.F., Ritchie, B.K., \& Slater, D. (2005). Systemic vulnerability and the origins of developmental states: Northeast and Southeast Asia in comparative perspective. International Organization, 59, 327-361.

ECA. (2017). Expanding and Strengthening Local Entrepreneurship for Structural Transformation in Africa. Addis Ababa: United Nations Economic Commission for Africa.

ECA and AU. (2011). Economic Report on Africa 2011: Governing Development in Africa - The Role of the State in Economic Transformation. Addis Ababa: UN Economic Commission for Africa/African Union.

Ekeh, P. (1975). Colonialism and the two publics in Africa: A theoretical statement. Comparative Studies in Society and History, 17(1), 91-112.

Evans, P.B., Rueschemeyer, D., \& Skocpol, T. (Eds.). (1985). Bringing the State Back In. Cambridge: Cambridge University Press.

Fafchamps, M. (2004). Market Institutions in Sub-Saharan Africa: Theory and Evidence. Cambridge, MA: MIT Press.

Fafchamps, M. (2011). Markets and the diffusion of institutional innovations. In J-P. Platteau \& R. Peccoud (Eds.), Culture, Institutions, and Development: New Insights into an Old Debate (pp. 143-159). London: Routledge.

Fan, S., Brzeska, J., Keyzer, M., \& Halsema, A. (2013). From Subsistence to Profit: Transforming Smallholder Farms. Washington, DC: International Food Policy Reseach Institute.

FAO and World Bank. (2009). Awakening Africa's Sleeping Giant: Prospects for Commercial Agriculture in the Guinea Savannah Zone and Beyond. Washington, DC: World Bank.

Felgenhauer, K., \& Wolter, D. (2008). Outgrower schemes: Why big multinationals link up with African smallholders. In OECD Development Centre (Ed.), Turning African Agriculture into a Business: A Reader (pp. 29-31). Paris: OECD Development Centre.

Fuglie, K., Gautam, M., Goyal, A., \& Maloney, W.F. (2020). Harvesting Prosperity: Technology and Productivity Growth in Agriculture. Washington, DC: World Bank Group.

Future State, Centre for the. (2005). Signposts to More Effective States: Responding to Governance Challenges in Developing Countries. Brighton, UK: Institute of Development Studies.

Gelb, A., Meyer, C., \& Ramachandran, V. (2013). Does poor mean cheap? Africa's industrial labor costs in comparative perspective. Working Paper 325. Washington, DC: Center fof Global Development.

Gelb, A., Meyer, C.J., \& Ramachandran, V. (2015). Development as diffusion: Manufacturing productivity and Africa's missing middle. In C. Monga \& J.Y. Lin (Eds.), The Oxford Handbook of Africa and Economiccs, Vol 1: Context and Concepts (pp. 115-135). Oxford: Oxford University Press.

Gollin, D., \& Goyal, R. (2017). Agricultural transformation in Tanzania: Linking rural to urban through domestic value chains. In C.S. Adam, P. Collier, \& B. Ndulu (Eds.), Tanzania: The Path to Prosperity (pp. 132-150). Oxford: Oxford University Press.

Gray, H. (2013). Industrial policy and the political settlement in Tanzania: Aspects of continuity and change since independence. Review of African Political Economy, 40(136), 185-201.

Gray, H. (2018). Turbulence and Order in Economic Development: Institutions and Economic Transformation in Tanzania and Vietnam. Oxford: Oxford University Press.

Gray, H., \& Whitfield, L. (2014). Reframing African political economy: Clientelism, rents and accumulation as drivers of capitalist transformation. Working Paper 14-159. London School of Economics and Political Science, Development Studies Institute. 
Grover Goswami, A., Medvedev, D., \& Olafsen, E. (2019). High-growth firms: Facts, Fiction, and Policy Options for Emerging Economies. Washington, DC: World Bank Group.

Haggblade, S., Hazell, P.B.R., \& Reardon, T. (Eds.). (2007). Transforming the Rural Nonfarm Economy: Opportunities and Threats in the Developing World. Baltimore, MD: Johns Hopkins University Press/IFPRI.

Handley, A. (2008). Business and the State in Africa: Economic Policy-making in the Neo-liberal Era. Cambridge: Cambridge University Press.

Harrison, A.E., Lin, J.Y., \& Xu, L.C. (2014). Explaining Africa's (dis)advantage. World Development, $63,59-77$.

Harrison, G. (2016). Rwanda: An agrarian developmental state. Third World Quarterly, 37(2), 354-370.

Hazell, P., Poulton, C., Wiggins, S., \& Dorward, A. (2010). The future of small farms: Trajectories and policy priorities. World Development, 38(10), 1349-1361.

Henley, D. (2015). Asia-Africa Development Divergence: A Question of Intent. London: Zed Books.

Hickey, S., Sen, K., \& Bukenya, B. (Eds.). (2015). The Politics of Inclusive Development: Interrogating the Evidence. Oxford: Oxford University Press.

Holmén, H. (2015). Is land grabbing always what it is supposed to be? Large-scale land investments in sub-Saharan Africa. Development Policy Review, 33(4), 457-478.

Hudson, D., Mcloughlin, C., Roche, C., \& Marquette, H. (2018). Inside the black box of political will: 10 years of findings from the Developmental Leadership Program. University of Birmingham: Developmental Leadership Program.

Hyden, G. (1983). No Shortcuts to Progress: African Development Management in Perspective. London: Heinemann.

Iacovone, L., Ramachandran, V., \& Schmidt, M. (2014). Stunted growth: Why don't African firms create more jobs? Working Paper 353. Washington, DC: Center for Global Development.

IFPRI. (2019). Global Food Policy Report 2019. Washington, DC: International Food Policy Research Institute.

IPPG. (2010). Beyond Institutions: Institutions and Organizations in the Politics and Economics of Growth and Poverty Reduction - A Thematic Synthesis of Research Evidence. Manchester, UK: Improving Institutions for Pro-Poor Growth Programme.

Jayne, T.S., Chamberlin, J., \& Benfica, R. (2018). Africa's unfolding economic transformation. Journal of Development Studies, 54(5), 777-787.

Juma, C. (2011). The New Harvest: Agricultural Innovation in Africa. Oxford: Oxford University Press.

Karugia, J., Ndirangu, L., Nyangito, H., \& Suri, T. (2010). Policy options for agriculture in Kenya. In C. S. Adam, P. Collier, \& N. Ndung'u (Eds.), Kenya: Policies for Prosperity (pp. 211-242). Oxford: Oxford University Press.

Kelsall, T. (2008). Going with the grain in African development? Development Policy Review, 26(6), $627-655$.

Kelsall, T. (2011). Rethinking the relationship between neo-patrimonialism and economic development in Africa. IDS Bulletin, 42(2), 76-87.

Kelsall, T. (2013). Business, Politics, and the State in Africa: Challenging the Orthodoxies on Growth and Transformation. London: Zed Books.

Kelsall, T. (2018a). Towards a universal political settlement concept: A response to Mushtaq Khan. African Affairs, 117(469), 656-669.

Kelsall, T. (2018b). Thinking and working with political settlements: The case of Tanzania. Working Paper 541. London: Overseas Development Institute.

Khan, M.H. (1995). State failure in weak states: A critique of new institutionalist explanations. In J. Harriss, J. Hunter, \& C.M. Lewis (Eds.), The New Institutional Economics and Third World Development (pp. 71-86). London: Routledge.

Khan, M.H. (2005). The capitalist transformation. In J.K. Sundaram \& E.S. Reinert (Eds.), The Origins of Development Economics: How Schools of Economic Thought Have Addressed Development (pp. 69-80). New Delhi and London: Tulika Books/Zed Books. 
Khan, M.H. (2010). Political settlements and the governance of growth-enhancing institutions. London: Economics Department, School of Oriental and African Studies, University of London.

Khan, M.H. (2012a). Governance and growth: History, ideology, and methods of proof. In A. Noman, K. Botchwey, H. Stein, \& J.E. Stiglitz (Eds.), Good Growth and Governance in Africa: Rethinking Development Strategies (pp. 51-79). Oxford: Oxford University Press.

Khan, M.H. (2012b). Beyond good governance: An agenda for developmental governance. In J.K. Sundaram \& A. Chowdhury (Eds.), Is Good Governance Good for Development? (pp. 151-182) London: Bloomsbury Academic/United Nations.

Khan, M.H. (2018). Political settlements and the analysis of institutions. African Affairs, 117(469), 636655.

Khan, M.H., \& Sundaram, J.K. (Eds.). (2000). Rents, Rent-seeking and Economic Development: Theory and Evidence from Asia. Cambridge: Cambridge University Press.

Kim, K., \& Leipziger, D.M. (1997). Korea: A case of government-led development. In D.M. Leipziger (Ed.), Lessons from East Asia (pp. 155-212). Ann Arbor, MI: University of Michigan Press.

Kirsten, J.F., Dorward, A.R., Poulton, C., \& Vink, N. (Eds.). (2009). Institutional Economics Perspectives on African Agricultural Development. Washington, DC: International Food Policy Research Institute.

Krishnan, A., Banga, K., \& Mendez-Parra, M. (2020). Disruptive technologies in agricultural value chains: Insights from East Africa. Working Paper 576. London: Overseas Development Institute.

Lazonick, W. (1991). Business Organization and the Myth of the Market Economy. Cambridge: Cambridge University Press.

Lazonick, W. (1992). Organization and Technology in Capitalist Development. Aldershot, UK: Edward Elgar.

Levy, B. (2014). Working with the Grain: Integrating Governance and Growth in Development Strategies. New York: Oxford University Press.

Lin, J.Y. (2012). New Structural Economics: A Framework for Rethinking Development and Policy. Washington, DC: World Bank.

Lin, J.Y., \& Monga, C. (2017). Beating the Odds: Jump-starting Developing Countries. Princeton, NJ: Princeton University Press.

Little, P.D., \& Watts, M.J. (Eds.). (1994). Living Under Contract: Contract Farming and Agrarian Transformation in Sub-Saharan Africa. Madison, WI: University of Wisconsin Press.

Losch, B., Fréguin-Gresh, S., \& White, E.T. (2012). Structural Transformation and Rural Change Revisited: Challenges for Late Developing Countries in a Globalizing World. Washington, DC: Agence Française de Développement and World Bank.

Lubeck, P.M. (Ed.). (1987). The African Bourgeoisie: Capitalist Development in Nigeria, Kenya, and the Ivory Coast. Boulder, CO: Lynne Rienner.

Matsumoto-Izadifar, Y. (2008). Africa can develop domestic agribusiness better. In OECD Development Centre (Ed.), Turning African Agriculture into a Business: A Reader (pp. 33-35). Paris: OECD Development Centre.

McKinsey Global Institute. (2010). Lions on the Move: The Progress and Potential of African Economies. Washington, DC: McKinsey \& Company.

McMillan, M., \& Headey, D. (2014). Introduction - Understanding structural transformation in Africa. World Development, 63, 1-10.

McMillan, M., Page, J., \& Wangwe, S. (2017a). Unlocking Tanzania's manufacturing potential. In C.S. Adam, P. Collier \& B. Ndulu (Eds.), Tanzania: The Path to Prosperity (pp. 151-169). Oxford: Oxford University Press.

McMillan, M., Page, J., Booth, D., \& te Velde, D.W. (2017b). Supporting economic transformation: An approach paper. London: Overseas Development Institute, Supporting Economic Development programme.

Meiksins Wood, E. (1999). The Origins of Capitalism: A Longer View. New York: Monthly Review Press. 
Mellor, J.W. (2017). Agricultural Development and Economic Transformation: Promoting Growth with Poverty Reduction. Cham, Switzerland: Palgrave Macmillan.

Mellor, J.W. (Ed.). (1995). Agriculture on the Road to Industrialization. Baltimore, MD: Johns Hopkins University Press.

Mills, G. (2010). Why Africa is Poor and What Africans Can Do About It. Johannesburg: Penguin.

Mills, G. (2019). The country which harnessed the wind? Working with Southern Africa's tobacco dependence. Discussion Paper 06/2019. Johannesburg: Brenthurst Foundation.

Monga, C. (2013). Winning the jackpot: Jobs dividends in a multipolar world. In J.E. Stiglitiz, J.Y. Lin, \& E. Patel (Eds.), The Industrial Policy Revolution II: Africa in the 21st Century (pp. 135-172). Basingstoke, UK: Palgrave Macmillan/International Economic Association.

Monga, C. (2019). Truth is the safest lie: A reassessment of development economics. In C. Monga \& J.Y. Lin (Eds.), The Oxford Handbook of Structural Transformation (pp. 659-671). Oxford: Oxford University Press.

Monga, C., \& Lin, J.Y. (2015). Introduction: Africa's evolving economic policy frameworks. In C. Monga \& J.Y. Lin (Eds.), The Oxford Handbook of Africa and Economics, Vol. II: Policies and Practices (pp. 1-20). Oxford: Oxford University Press.

Monga, C., \& Lin, J.Y. (2019a). Introduction: Structural transformation - Overcoming the curse of destiny. In C. Monga \& J.Y. Lin (Eds.), The Oxford Handbook of Structural Transformation (pp. 1-32). Oxford: Oxford University Press.

Monga, C., \& Lin, J.Y. (Eds.). (2019b). The Oxford Handbook of Structural Transformation. Oxford: Oxford University Press.

Moore, M. (1988). Economic growth and the rise of civil society: Agriculture in Taiwan and South Korea. In G. White (Ed.), Developmental States in East Asia (pp. 113-152). London: Macmillan.

Moore, M., \& Unsworth, S. (2010). An Upside Down View of Governance. Brighton: Institute of Development Studies, Centre for the Future State.

Mueller, V., \& Thurlow, J. (Eds.). (2019). Youth and Jobs in Rural Africa: Beyond Stylized Facts. Oxford: Oxford University Press/IFPRI.

Myers, R.H., \& Ching, A. (1964). Agricultural development in Taiwan under Japanese colonial rule. Journal of Asian Studies, 23(4), 555-570.

Ncube, M. (2015). Inclusive growth in Africa: Current performance and prospects. In E. Zedillo, O. Cattaneo, \& H. Wheeler (Eds.), Africa at a Fork in the Road: Taking Off or Disappointment Once Again? (pp. 87-119) New Haven, CT: Yale University Center for the Study of Globalization.

Ndulu, B.J., Chakraborti, L., Lijane, L., Ramachandran, V., \& Wolgin, J. (2007). Challenges of African Growth: Opportunities, Constraints, and Strategic Directions. Washington, DC: World Bank.

Nelson, R., Dosi, G., Helfat, C., Pyka, A., Saviotti, P.P., Lee, K., . . Winter, S. (2018). Modern Evolutionary Economics: An Overview. Cambridge: Cambridge University Press.

Newman, C., Page, J., Rand, J., Shimeles, A., Söderbom, M., \& Tarp, F. (2016). Made in Africa: Learning to Compete in Industry. New York: Brookings Institution Press.

North, D.C., Wallis, J.J., \& Weingast, B.R. (2009). Violence and Social Orders: A Conceptual Framework for Interpreting Recorded Human History. Cambridge: Cambridge University Press.

North, D.C., Wallis, J.J., Webb, S.B., \& Weingast, B.R. (Eds.). (2013). In the Shadow of Violence: Politics, Economics, and the Problems of Development. Cambridge: Cambridge University Press.

Obasanjo, O., Mills, G., \& van der Merwe, E. (2018). Let's not talk about agriculture, but agri-business. Discussion Paper 12/2018. Johannesburg: Brenthurst Foundation.

Ohno, I., \& Ohno, K. (2012). Dynamic capacity development: What Africa can learn from industrial policy formulation in East Asia. In A. Noman, K. Botchwey, H. Stein, \& J.E. Stiglitz (Eds.), Good Growth and Governance in Africa (pp. 221-245). Oxford: Oxford University Press.

Oqubay, A., \& Ohno, K. (Eds.). (2019). How Nations Learn: Technological Learning, Industrial Policy, and Catch-up. Oxford: Oxford University Press.

Oya, C. (2012). Contract farming in sub-Saharan Africa: A survey of approaches, debates and issues. Journal of Agrarian Change, 12(1), 1-33. 
Ponte, S., \& Brockington, D. (2020). From pyramid to pointed egg? A 20-year perspective on poverty, prosperity, and rural transformation in Tanzania. African Affairs, 119(475), 203-223.

Poulton, C., Dorward, A., \& Kydd, J. (2010). The future of small farms: New directions for services, institutions, and intermediation. World Development, 38(10), 1413-1428.

Pritchett, L., Sen, K., \& Werker, E. (2017). Deals and Development: The Political Dynamics of Growth Episodes. Oxford: Oxford University Press.

Putzel, J., \& Di John, J. (2012). Meeting the Challenges of Crisis States. London: London School of Economics/Crisis States Programme.

Radelet, S. (2010). Emerging Africa: How 17 Countries Are Leading the Way. Washington, DC: Center for Global Development.

Ramachandran, V. (2015). Productivity, jobs, and growth in Africa: Six pieces of the puzzle. In E. Zedillo, O. Cattaneo, \& H. Wheeler (Eds.), Africa at a Fork in the Road: Taking Off or Disappointment Once Again (pp. 121-131). New Haven, CT: Yale University Center for the Study of Globalization.

Ramachandran, V., Gelb, A., \& Kedia Shah, M. (2009). Africa's Private Sector: What's Wrong with the Business Environment and What to Do about It. Washington, DC: Center for Global Development.

Reardon, T. (2015). The hidden middle: The quiet revolution in the midstream of agrifood value chains in developing countries. Oxford Review of Economic Policy, 31(1), 45-63.

Reardon, T., Barrett, C.B., Berdegué, J.A., \& Swinnen, J.F.M. (2009). Agrifood industry transformation and small farmers in developing countries. World Development, 37(11), 1717-1727.

Reinert, E.S. (2007). How Rich Countries Got Rich ... And Why Poor Countries Stay Poor. London: Constable \& Robinson.

Rodrik, D. (2013). Unconditional convergence in manufacturing. Quarterly Journal of Economics, 121(1), 165-204.

Sangho, Y., Labaste, P., \& Ravry, C. (2011). Growing Mali's mango exports: Linking farmers to market through innovations in the value chain. In P. Chuhan-Pole \& M. Angwafo (Eds.), Yes Africa Can: Success Stories from a Dynamic Continent (pp. 167-183). Washington, DC: World Bank.

Sender, J. (1999). Africa's economic performance: Limitations of the current consensus. Journal of Economic Perspectives, 13(3), 89-114.

Sender, J., \& Smith, S. (1986). The Development of Capitalism in Africa. London: Methuen.

Shin, G-W. (2006). Neither "sprouts" nor "offspring": The agrarian roots of Korean capitalism. In Y-S. Chang \& S.H. Lee (Eds.), Transformations in Twentieth Century Korea (pp. 33-63). London: Routledge.

Skarstein, R. (2005). Economic liberalization and smallholder productivity in Tanzania: From promised success to real failure, 1985-1998. Journal of Agrarian Change, 5(3), 334-362.

Skocpol, T. (1979). States and Social Revolutions: A Comparative Analysis of France, Russia, and China. Cambridge: Cambridge University Press.

Staritz, C., \& Whitfield, L. (2017). What is required for African-owned firms to enter new export sectors? Conceptualizing technological capabilities within global value chains. CAE Working Paper 2017:1. Roskilde University Center of African Economies.

Stiglitz, J.E., \& Lin, J.Y. (Eds.). (2013). The Industrial Policy Revolution I: The Role of Government beyond Ideology. Basingstoke, UK: Palgrave Macmillan/IEA.

Studwell, J. (2013). How Asia works: Success and Failure in the World's Most Dynamic Region. London: Profile Books.

Teschke, B. (2003). The Myth of 1648: Class, Geopolitics and the Making of Modern International Relations. London: Verso.

Timmer, C.P. (1988). The agricultural transformation. In H. Chenery, \& T.N. Srinivasan (Eds.), Handbook of Development Economics, Volume 1 (pp. 276-331). Amsterdam: Elsevier. 
Timmer, C.P. (2007). The structural transformation and the changing role of agriculture in economic development: Empirics and implications (Wendt Lecture). Washington, DC: American Enterprise Institute.

Timmer, C.P. (2015). Food Security and Scarcity: Why Ending Hunger is So Hard. Philadelphia, PA: University of Pennsylvania Press.

Timmer, C.P. (2016). The role of agriculture in "catching up": A Gershenkronian perspective. In M. Andersson \& T. Axelsson (Eds.), Diverse Development Paths and Structural Transformation in the Escape from Poverty (pp. 68-90). Oxford: Oxford University Press.

Tomich, T.P., Kilby, P., \& Johnston, B.F. (1995). Transforming Agrarian Economies: Opportunuties Seized, Opportunities Missed. Ithaca, NY: Cornell University Press.

Toulmin, C., \& Quan, J. (Eds.). (2000). Evolving Land Rights, Policy and Tenure in Africa. London: DFID/IIED/NRI.

Tsakok, I. (2011). Success in Agricultural Transformation: What It Means and What Makes It Happen. Cambridge: Cambridge University Press.

Tschirley, D., Reardon, T., Dosilager, M., \& Snyder, J. (2015). The rise of a middle class in East and Southern Africa: Implications for food system transformation. Journal of International Development, 27, 628-646.

Tyce, M. (2020). A "private-sector success story"? Uncovering the role of politics and the state in Kenya's horticultural export sector. Journal of Development Studies, 56(10), 1877-1893.

van de Walle, N. (2001). African Economies and the Politics of Permanent Crisis, 1979-1999. Cambridge: Cambridge University Press.

Warren, B. (1980). Imperialism: Pioneeer of Capitalism. London: Verso.

Weatherspoon, D.D., \& Reardon, T. (2003). The rise of supermarkets in Africa: Implications for agrifood systems and the rural poor. Development Policy Review, 21(3), 333-355.

Whitfield, L. (2012). How countries become rich and reduce poverty: A review of heterodox explanations of economic development. Development Policy Review, 30(3), 239-260.

Whitfield, L. (2018). Economies after Colonialism: Ghana and the Struggle for Power. Cambridge: Cambridge University Press.

Whitfield, L., Therkildsen, O., Buur, L., \& Kjær, A.M. (2015). The Politics of African Industrial Policy: A Comparative Perspective. Cambridge: Cambridge University Press.

Wiggins, S. (2018). Agricultural growth trends in Africa. APRA Working Paper 13. Brighton, UK: Future Agricultures Consortium.

Wolter, D. (2008a). Tanzania - Why a potential food exporter still imports food. In OECD Development Centre (Ed.), Turning African Agriculture into a Business: A Reader (pp. 55-57). Paris: OECD Development Centre.

Wolter, D. (2008b). Linking smallholders to markets: What role for donors? In OECD Development Centre (Ed.), Turning African Agriculture into a Business: A Reader (pp. 37-39). Paris: OECD Development Centre.

World Bank Group/Government of Rwanda. (2019). Future Drivers of Growth in Rwanda: Innovation, Integration, Agglomeration, and Competition. Washington, DC: World Bank. 